\title{
POTENTIAL EFFECTS OF CLIMATE CHANGE ON FRESHWATER ECOSYSTEMS OF THE NEW ENGLAND/MID-ATLANTIC REGION
}

\author{
MARIANNE V. MOORE,' MICHAEL L. PACE,' JOHN R. MATHER, ${ }^{3}$ PETER S. MURDOCH, ${ }^{4}$ \\ ROBERT W. HOWARTH, ${ }^{5}$ CAROL L. FOLT, ${ }^{6}$ CELIA Y. CHEN, ${ }^{6}$ HAROLD F. HEMOND, ${ }^{7}$ \\ PATRICIA A. FLEBBE ${ }^{8}$ AND CHARLES T. DRISCOLL 9 \\ 'Department of Biological Sciences, Wellesley College, Wellesley, MA 02181-8283, USA \\ 'Institute of Ecosystem Studies, Box AB, Millbrook, NY 12545. USA \\ '216 Newark Hall, Geography Department, University of Delaware, Newark, DE 19716. USA \\ ${ }^{4}$ US Geological Survey, 425 Jordan Road, Troy, NY 12180, USA \\ 'Section of Ecology \& Systematics, Corson Hall, Cornell University, Ithaca, NY 14853, USA \\ ${ }^{6}$ Department of Biological Sciences, 6044 Gilman Laboratory, Darmouth College, Hanover, NH 03755-3576, USA \\ 'Ralph Parsons Laboratory, Department of Civil and Environmental Engineering, Massachusetts Institute of Technology, \\ Cambridge, MA 02139, USA \\ ${ }^{8}$ Department of Fisheries and Wildlife, Virginia Tech, Blacksburg. VA 25061-0321, USA \\ ${ }^{9}$ Department of Civil \& Environmental Engineering, Syracuse University, Syracuse, NY 13244, USA
}

\begin{abstract}
Numerous freshwater ecosystems, dense concentrations of humans along the eastern seaboard, extensive forests and a history of intensive land use distinguish the New England/Mid-Atlantic Region. Human population densities are forecast to increase in portions of the region at the same time that climate is expected to be changing. Consequently, the effects of humans and climatic change are likely to affect freshwater ecosystems within the region interactively. The general climate, at present, is humid continental, and the region receives abundant precipitation. Climatic projections for a $2 \times \mathrm{CO}_{2}$ atmosphere, however, suggest warmer and drier conditions for much of this region. Annual temperature increases ranging from $3-5^{\circ} \mathrm{C}$ are projected, with the greatest increases occurring in autumn or winter. According to a water balance mode!, the projected increase in temperature will result in greater rates of evaporation and evapotranspiration. This could cause a 21 and $31 \%$ reduction in annual stream flow in the southern and northern sections of the region, respectively, with greatest reductions occurring in autumn and winter. The amount and duration of snow cover is also projected to decrease across the region, and summer convective thunderstorms are likely to decrease in frequency but increase in intensity.

The dual effects of climate change and direct anthropogenic stress will most likely alter hydrological and biogeochemica! processes, and, hence, the flora! and fauna! communities of the region's freshwater ecosystems. For example, the projected increase in evapotranspiration and evaporation could eliminate most bog ecosystems, and increases in water temperature may increase bioaccumulation, and possibly biomagnification, of organic and inorganic contaminants. Not a!! change may be adverse. For example, a decrease in runoff may reduce the intensity of ongoing estuarine eutrophication, and acidification of aquatic habitats during the spring snowmelt period may be ameliorated.

Recommendations for future monitoring efforts include: (1) extending and improving data on the distribution, abundance and effect of anthropogenic stressors (non-point pollution) within the region; and (2) improving scientific knowledge regarding the contemporary distribution and abundance of aquatic species. Research recommendations include: (1) establishing a research centre(s) where field studies designed to understand interactions between freshwater ecosystems and climate change can be conducted; (2) projecting the future distribution, activities and direct effects of humans within the region; (3) developing mathematical analyses, experimental designs and aquatic indicators that distinguish between climatic and anthropogenic effects on aquatic systems; (4) developing and refining projections of climate variability such that the magnitude, frequency and seasonal timing of extreme events can be forecast; and (5) describing quantitatively the flux of materials (sediments, nutrients, metals) from watersheds characterized by a mosaic of land uses. (C) 1997 by John Wiley \& Sons, Ltd.
\end{abstract}

Hydrol. Process., Vol. 11, 925-947 (1997).

(No. of Figures: 4 No. of Tables: 4 No. of Refs: 120)

KEY WORDs climate change; Mid-Atlantic and New England; freshwater ecosystems; anthropogenic stressors; interactive effects 


\section{INTRODUCTION}

Water-rich, extensively forested and densely populated by humans along the eastern seaboard, this region extends from eastern maritime Canada to Chesapeake Bay and westwards to include much of the Ohio River drainage basin. In this region, past deforestation, present reforestation and expansion of the human population are key factors that impinge upon considerations of climate change and its effect on freshwaters. In this paper, we explore interactions between climate change and direct anthropogenic stress on the freshwater ecosystems of the region. We contend that the dual effect of climate change and direct anthropogenic stress could be as equally transforming as the historical land use alterations that affected freshwater ecosystems within the region during the late eighteenth and nineteenth centuries.

The paper is structured in the following manner. We begin by defining the region's boundaries and its distinctive features including its unique history of intensive land use. The current and projected climates for the region are presented, and a brief description of urban climates and the possibilities they offer for global climate change research then follows. Five examples demonstrating how climate change and direct human effects may interactively affect aquatic ecosystems in the region are presented next, and recommendations for future research and monitoring are discussed.

\section{BOUNDARIES}

This region projects beyond the conventional state boundaries frequently used to define the New England/ Mid-Atlantic area (Figure 1 in Leavesley et al., this volume). Owing to inclusion of much of the Ohio River drainage system, the region extends south-west to include the states of West Virginia, Kentucky and much of Ohio. Nova Scotia and eastern New Brunswick define the northernmost portion of the region. Unless otherwise noted, regional statistics in this paper were calculated for the entire land area defined by the states listed in Table I. Although regional statistics do not include Nova Scotia and the appropriate portions of New Brunswick, Tennessee, Indiana, Illinois, North Carolina and Virginia, many of the ideas in this paper can be extended to these areas.

Table I. Percentage land cover or use of non-federal land (excluding surface water) per state, region, and US in 1992. Percentages were derived using data from the 1992 National Resources Inventory (US DOA, 1994). Values in parentheses in state and forested columns represent the rankings of the top 12 forested states in the US and \% forested of total land (federal plus non-federal land), respectively (Alampi, 1994). 'Developed' refers to urban areas or those cities with more than 2500 individuals. Land use percentages for the US do not sum to $100 \%$ because rangeland, absent from the New England/Mid-Atlantic Region, was omitted from the table

\begin{tabular}{|c|c|c|c|c|c|}
\hline State (Rank) & $\%$ Developed & $\begin{array}{l}\% \text { Forested } \\
(\% \text { of total land })\end{array}$ & $\%$ Crop & $\%$ Pasture & $\%$ Minor use \\
\hline Connecticut (12) & 26.7 & $57.6(59)$ & 7.5 & 3.6 & 4.6 \\
\hline Delaware & 16.9 & 29.1 & $41 \cdot 2$ & $2 \cdot 1$ & 10.7 \\
\hline Kentucky & 6.9 & 43 & 21.2 & 24.4 & 4.5 \\
\hline Maine (1) & 3.6 & $90(90)$ & 2.3 & 0.6 & 3.6 \\
\hline Maryland & 18.2 & 39.2 & 27.7 & 9 & 5.9 \\
\hline Massachusetts (9) & $27 \cdot 1$ & $57.4(62)$ & 5.6 & 3.5 & 6.4 \\
\hline New Hampshire (2) & 11.4 & $79.4(88.0)$ & 2.9 & 2 & 4.4 \\
\hline New Jersey & 34.9 & 38.8 & 14.3 & 3.5 & 8.5 \\
\hline New York (9) & 10.1 & $57.6(62.0)$ & 18.8 & $10 \cdot 1$ & 3.3 \\
\hline Ohio & 13.9 & 25.8 & 46.5 & 8.8 & 5 \\
\hline Pennsylvania (12) & 12.3 & $55.1(59)$ & $20 \cdot 1$ & 8.4 & $4 \cdot 1$ \\
\hline Rhode Island (11) & 28.7 & $59.4(60)$ & 3.8 & 3.7 & 4.5 \\
\hline Vermont (4) & 5.9 & $75 \quad(76)$ & 11.5 & 6.3 & 1.4 \\
\hline West Virginia (3) & 4.9 & $74.5(79)$ & 6.5 & 11.4 & 2.8 \\
\hline Region & 11.1 & 55.3 & 19.6 & 9.7 & 4.2 \\
\hline USA & 6.2 & 26.6 & 27.5 & 8.5 & 6 \\
\hline
\end{tabular}

HYDROLOGICAL PROCESSES, VOL. 1 I, 925-947 (1997) 


\section{DISTINCTIVE FEATURES}

Freshwater ecosystems in the New England/Mid-Atlantic Region are abundant and diverse. This is a result, in part, of the Wisconsin glaciation, the altitudinal relief of the Appalachian Mountains and the presence of the Atlantic coast. For example, 11500 lakes and reservoirs (surface area $>1$ ha) occur in New England, New York and New Jersey alone (Paulsen et al., 1991). Of the natural lakes, most are kettle lakes or of glacial origin. Based on total phosphorus and chlorophyll a data, 38\% are oligotrophic, $42 \%$ mesotrophic and $21 \%$ eutrophic to hypereutrophic. In the coastal lowlands, however, where humans are concentrated, a much greater percentage of these lakes (51\%) are eutrophic and hypereutrophic (US EPA, 1994). South of the Wisconsin glaciation (all mid-Atlantic and interior states excluding New York), natural lakes are largely absent and are-replaced by reservoirs and numerous streams. Lotic habitats range from cold water streams in the Appalachian Mountains to large, turbid rivers along the Atlantic coastal plain. Most streams throughout the region have been classified as perennial runoff streams that flow throughout the year but have low baseflows with little between-year variation in low flow (Poff, 1992). More than 480 estuaries $\left(>2 \mathrm{~km}^{2}\right)$ also occur here, and this density is second only to that in the south-eastern region of the US (K. Summers, EMAP, personal communication). These estuaries include many large, culturally rich and economically important systems such as Chesapeake Bay, Delaware Bay, the Hudson River, Long Island Sound, Massachusetts Bay and the Bay of Fundy. Finally, at least $6 \%$ of the land area is covered by wetlands and, of this, $92 \%$ is freshwater wetlands (R. Tiner, USFWS, personal communication). Of the freshwater wetlands, most located south of Maine and east of the Appalachians are red maple swamps, whereas bogs are prevalent in the interior of Maine and the Canadian maritimes. Riparian wetlands predominate in the Ohio River drainage.

More humans reside within the New England/Mid-Atlantic Region than in any other region of North America. Humans, however, are largely concentrated in coastal areas where population density is projected to increase at the same time that climate is expected to change (Culliton et al., 1990). The proportion of urban land in coastal states of the region is 2-5 times greater than the average for the US (Table I). Indeed, eight of the ten most urban states in the USA occur in this region, and all are coastal except Ohio (Morgan et al., 1993). Estuaries are probably affected most by coastal metropolitan areas via urban runoff, combined sewer overflows, municipal and industrial wastes and harbour dredging. These effects are likely to increase (Kennedy, 1990) because the coastal population of the New England/Mid-Atlantic area is expected to increase by four million people, the current combined population of Connecticut and Rhode Island, by the year 2010 (Culliton et al., 1990). Importantly, however, humans are unevenly distributed in the region. Some areas are largely rural. For example, Maine, Vermont and West Virginia are ranked among the most rural states on the basis of land use (Table I; Morgan et al., 1993). Nevertheless, humans currently, and in the past, have greatly modified the landscape and freshwater ecosystems throughout the entire New England/ Mid-Atlantic Region, including the most rural areas.

The long history of intensive land use is another signature feature of the New England/Mid-Atlantic Region. Forest clearance, during the late eighteenth and nineteenth centuries, was probably the most obvious alteration to the landscape. At the time of European settlement, the hardwoods forest of eastern North America stretched nearly unbroken from the Atlantic Coast to the Mississippi River (Greeley, 1925; Whitney, 1994). According to the diaries and letters of Europeans, it was 'an ocean of woods', a place where 'a savage might skulk from the Hudson to Lake Erie without once exposing himself to the glare of the sun' (Whitney, 1994). This virgin forest, however, was almost entirely swept off the landscape and converted to farmland. or burned 'for domestic and industrial purposes (Whitney, 1994). The maximum extent of forest clearance was remarkable. Historical records reveal that approximately $80-90 \%$ of the wooded area in portions of central Massachusetts and eastern New York had been removed by the mid- 1800s (Foster, 1992; reviewed by Whitney, 1994).

In addition to forest clearance, changes were also occurring in freshwater ecosystems. Increased stream flow undoubtedly resulted from forest removal, because forests were no longer transpiring large quantities of 
water during the growing season. Contemporary deforestation experiments of entire watersheds in the East have increased stream flow from $20-40 \%$ (Lee, 1980) or $25 \mathrm{~mm}$ for each $10 \%$ decrease in forest cover (Bosch and Hewlett, 1982). Thus, during much of the nineteenth century, forest clearance and increased stream flow, together with the continued expansion of agriculture, resulted in soil erosion and massive increases in sedimentation rates within lakes and other aquatic systems. For example, a fourfold increase in sediment deposition occurred at this time at several sites in Chesapeake Bay (Brush, 1986), and sedimentation caused the abandonment of coastal port towns (Whitney, 1994). Also, large-scale drainage of wetlands began in the latter half of the nineteenth century. Thus, just as agriculture was largely responsible for forest clearance, it was also the major driving force behind the destruction of wetlands (Tiner, 1984). Loss of wetlands between pre-settlement times and the 1980s was greatest in the Midwest (e.g. 90\% of wetland area, Ohio). Extent of loss, however, was considerable in the Mid-Atlantic states (58\%), but much less in New England (25\%) (Dahl, 1990).

During the last 100 years, farm abandonment and the decline of rural agriculture resulted in rapid reforestation in much of the eastern United States (Foster, 1995; Whitney, 1994). For example, two million acres of cleared land were reforested from 1880 to 1900 in Vermont, New Hampshire and Maine at the same time that 11000 farms were abandoned (Robinson, 1988). The pattern, of farm expansion and contraction, occurred in areas to the west, such as Ohio and Pennsylvania, and it continues today along the western margin of Appalachia (Whitney, 1994). Importantly, these major historical shifts in land use resulted more from changing social and economic factors than a decline in soil fertility or a regional climatic shift (Foster, 1995; Whitney, 1994).

Today, nine of the 12 most forested states in the USA occur in the New England/Mid-Atlantic Region, and $59-90 \%$ of the total land area of these states is covered in forest (Table I; Figure 1 in Leavesley et al., this volume). In New England and New York state, forest harvesting is proceeding much more slowly than growth (Smith, 1990; Foster, 1995). Consequently, the forest is characterized by continual ageing and growth resulting in a net increase in stored carbon (Wofsy et al., 1993). Since World War II, however, the forest has become increasingly fragmented into individual parcels of relatively small land area (Foster, 1995) as more urban dwellers purchase 'a piece of the woods'.

Although forests dominate the landscape, farming and mining, and, increasingly, urbanization represent important land uses in localized portions of the region (Figure 1 in Leavesley et al., this volume; Table I) (Alampi, 1994; US DOA, 1994). Suburbanization and urbanization represent a type of land use that has increased substantially since World War II (Figure 1). For example, 2.75 million acres of land in the New England/Mid-Atlantic Region were converted to urban or suburban use between 1982 and 1992 (US DOA, 1994). When expressed as a proportion of non-federal land area, an additional $1.6 \%$ of the region was developed during the IO-year period, a rate nearly twice that observed for the entire USA $(0.9 \%$ per 10 year) over the same time period.

At present, the most pervasive anthropogenic stressor affecting freshwater ecosystems in the region is a diverse group of non-point source pollutants (US EPA, 1994). For example, the Northeast receives among the highest inputs of acid deposition of any region in the United States (Husar et al., 1991; Ollinger $\boldsymbol{e} t$ al., 1993). The annual average $\mathbf{~ p H}$ of rain and snow in the Catskill and Adirondack Mountains of New York is about 4.3 (Murdoch, 1991). The anion content of precipitation is dominated by sulfate (roughly two-thirds), with about one-third attributed to nitrate and other minor anions (Driscoll et al., 1991; Murdoch, 1991). There is a gradient of decreasing atmospheric deposition of sulfur and nitrogen from New York to Maine (Ollinger $\boldsymbol{e} t$ al., 1993). In western Virginia (Shenandoah River drainage), levels of acidic deposition are as high as those in the north-eastern US, and the mountain streams there are at considerable risk of damage (Cosby et al., 1991).

Additional constituents of non-point pollution (Figure 2) were identified and ranked for the New England/Mid-Atlantic Region using data extracted from the National Water Quality Inventory (1992) (US EPA, 1994). This US inventory is compiled using data submitted by individual states every two years as mandated by the Clean Water Act of 1972. These data, however, must be viewed cautiously 


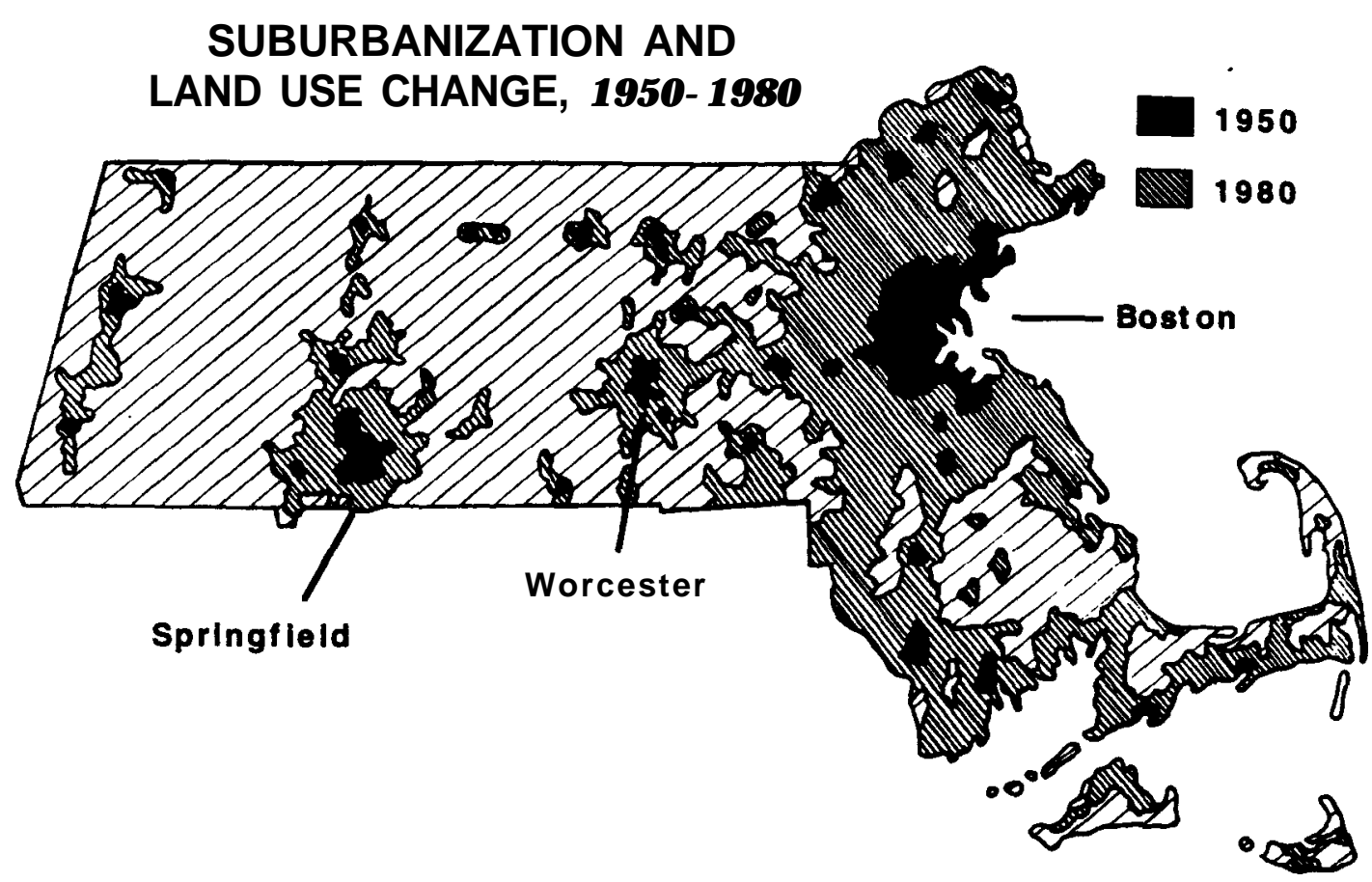

Figure I. Changes in the spatial extent of suburbanization in the state of Massachusetts during the last half of the twentieth century. The cities of Boston Worcester and Springfield, former agricultural and industrial towns, have converted to residential communities as the human population increased and road transportation improved (Foster, 1995). Modified from Wilkie and Tager (1991) and Foster (1995)

because each state monitors only a small percentage of its aquatic ecosystems, differences in assessment methods exist between and within states and sampling sites are not chosen randomly. Despite the limitations of the data, this inventory is the only information available for anthropogenic stressors across the region.

Nutrients, siltation and pathogens (indicator bacteria) were considered to be among the top four causes of water quality impairment in lakes, streams and estuaries (Figure 2). Nutrients were the top cause of impairment in lakes and estuaries, whereas siltation caused the greatest proportion of impaired river miles throughout the region (Figure 2). Metals caused substantial impairment in rivers and streams (33\% of impaired river miles), but not in lakes or estuaries. Eighty-five percent of the metal-impaired streams are located in West Virginia, Pennsylvania and the Ohio River valley where acid mine drainage is a severe problem. The toxicity of heavy metals coupled with the smothering effect of iron precipitates and low pH have rendered many streams sterile (Pennsylvania Department of Environmental Resources, 1994). Organic contaminants caused comparatively little impairment in lakes, streams or estuaries (Figure 2), and metals caused little impairment in lakes and estuaries $\left(2-3.5 \%\right.$ of impaired lake acres and $\mathbf{k m}^{2}$ of estuaries, respectively). This, however, reflects a lack of sampling by many states rather than lack of a problem. For example, state-wide fish consumption advisories for mercury were recently adopted for all lakes and streams or all lakes in Massachusetts, Maine, Vermont and New York state (D. Switzer, US EPA, personal communication). A major source of this mercury is fossil fuel combustion (e.g. coal) and subsequent atmospheric deposition on to the landscape (Driscoll et al., 1994).

Clearly, humans continue to influence aquatic ecosystems throughout the region. Consequently, an analysis of the effects of climatic change for this region must acknowledge that climatic effects are likely to interact with direct anthropogenic stressors. 

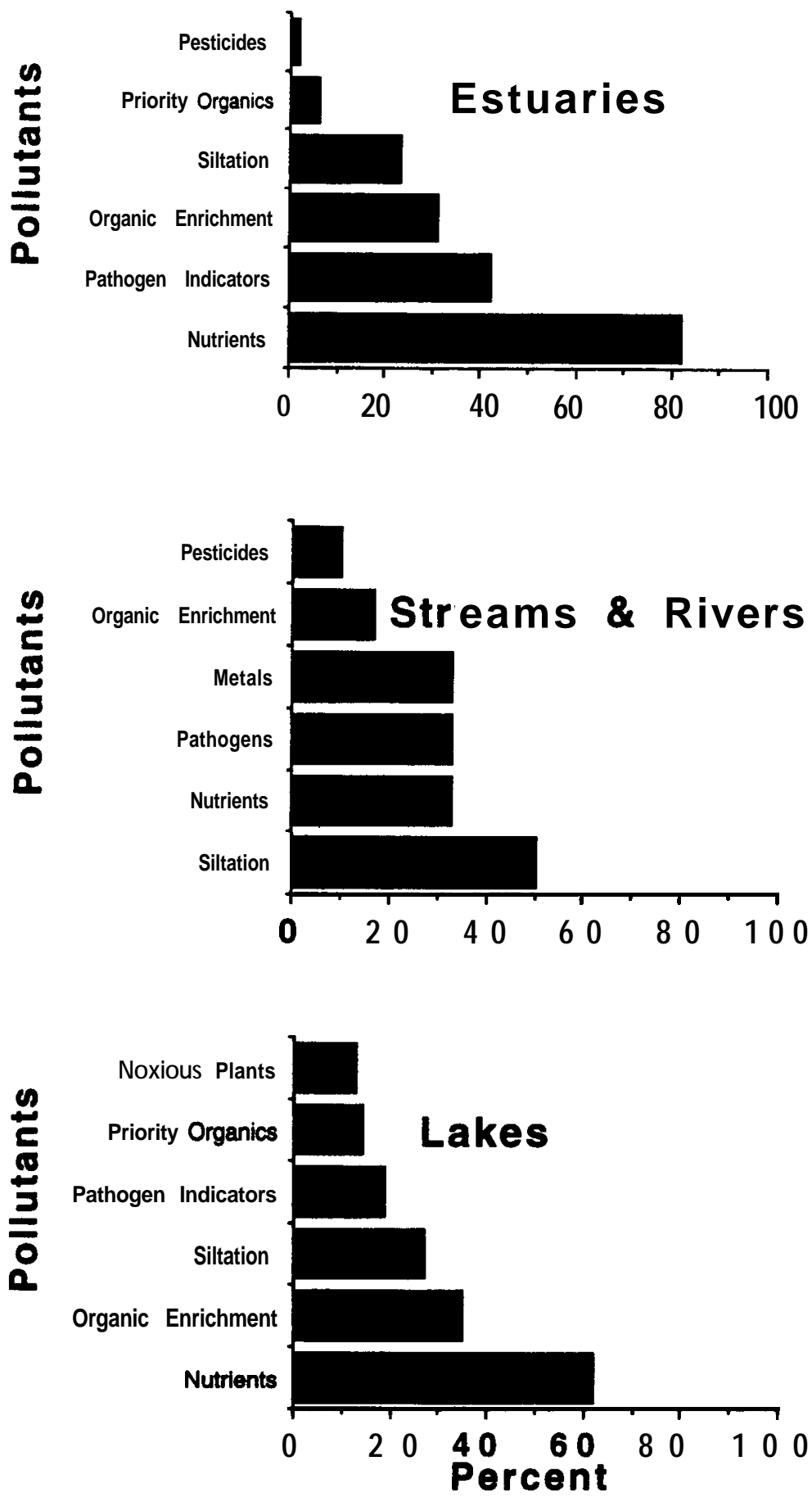

Figure 2. Percentage of assessed square miles of estuaries, river miles, and lake acres impaired (altered enough to affect human use or aquatic life) by pollutants in the New England/Mid-Atlantic Region. Percentages were derived by combining information from the National Water Quality Inventory (1992) (US EPA, 1994) for all states listed in Table I. Only the top six pollutants causing the greatest percentage impairment per habitat are shown. Note that relative percentages may reflect human bias more than reality, because water bodies are non-randomly selected for monitoring 


\section{PRESENT AND PROJECTED CLIMATE}

The New England/Mid-Atlantic Region was divided into two geographical sections (Figure 3) for climatic analysis. The present climate of the area is generally humid continental with warm to hot summers (mean July temperature $=20-25^{\circ} \mathrm{C}$ ), fairly high humidity and cool to cold winters (mean January temperature $=0-5^{\circ} \mathrm{C}$ in the southern section and -5 to $-10^{\circ} \mathrm{C}$ in the northern section). The region receives abundant precipitation ranging from $1350 \mathrm{~mm} / \mathrm{yr}$ in the southern interior states to $1500 \mathrm{~mm} / \mathrm{yr}$ in the northern coastal areas. Annual variability in precipitation is lower in the Northeast than in any other region of the US, with extremes departing only about 10\% from the mean (Miller and Miller, 1992). Snowfall is heavy in the northern section $(2000 \mathrm{~mm} / \mathrm{yr})$ and in the higher elevation areas of the southern section $(1000 \mathrm{~mm} / \mathrm{yr})$. The current natural vegetation of the region is deciduous forest grading to coniferous forest in the more northern areas and at higher altitudes.

During the past 150 years, air temperature has increased gradually over the whole region (Jones and Bradley, 1992). For example, in central New England (Hanover, NH), mean annual air temperature has increased $\left(+1.7^{\circ} \mathrm{C}\right)$ and mean summer air temperature has increased $\left(+2.2^{\circ} \mathrm{C}\right)$ during the last 150 years (Hamburg and Cogbill, 1988). These increases are similar to those observed at Amherst, MA (Bradley et al., 1987). Similarly, water temperatures in the Hudson River have increased $0.12^{\circ} \mathrm{C}$ per decade between 1920 and 1990 (Ashizawa and Cole, 1994). Normal climatic variability, however, could be responsible for these temperature increases. Alternatively, they might even be related to a general warming from the rather cold climatic conditions existing during the 'Little Ice Age' from the 1600 s to the 1800 s. If increasing $\mathrm{CO}_{2}$ is the only forcing factor, the 30 years of decreasing temperatures from 1945 to 1975 become difficult to explain.

Global circulation models (GCMs) can be used to obtain estimates of temperature and precipitation conditions under various future environmental scenarios, and these models provide essentially the only technique available at present to estimate quantitatively the climatic effect of increasing $\mathrm{CO}_{2} . \mathrm{GCMs}$, however, are imperfect, and projections on a regional scale are especially uncertam. Thus, while we are forced to consider the output from GCMs we should always be aware of their limitations (Hayes, 1991).

Climatic projections from four GCMs [GISS, (Goddard Institute of Space Studies), Hansen et al., 1988; OSU (Oregon State University), Schlesinger and Zhao, 1989; UKMO (United Kingdom Meteorological Office), Wilson and Mitchell, 1987; GFDL (Geophysical Fluid Dynamics Laboratory), Manabe and Wetherald, 1987] provide estimates of seasonal changes in air temperature and precipitation under conditions of a future doubling of $\mathrm{CO}_{2}$. Temperature is projected to increase across the entire region during all seasons (Figure 3). The temperature increase in the southern section of the region ranges from $+3.6^{\circ} \mathrm{C}$ in summer to $+4.4^{\circ} \mathrm{C}$ in autumn. In the northern section, slightly greater temperature increases are expected, ranging from $+4.0^{\circ} \mathrm{C}$ in autumn to $+5.0^{\circ} \mathrm{C}$ in the winter season. Precipitation is generally expected to increase in winter and spring in both sections of the region, but in summer and fall significant decreases in precipitation are predicted in both sections (except for a small increase in summer in the southern portion of the region) (Figure 4). On an annual basis, a small increase in precipitation might be expected in the southern portion of the region and a slight decrease in precipitation in the northern portion.

The temperature and precipitation projections described above were entered into a climatic water budget developed by Thomthwaite and Mather (1955). This water budget was used to project water surplus, water deficit, stream flow and snow cover in the region (Feddema and Mather, 1992; Hodny and Mather, 1995). A water deficit represents the difference between the climatic demand for water and the actual water use by plants, while a water surplus is the amount of precipitation exceeding the climatic water need once the soil is remoistened, and will be ultimately lost as stream flow. According to the water budget, there should be a genera1 shift to drier conditions in the region (Table II), because the projected increase in temperature will result in a greater increase in evapotranspiration than the projected increase in precipitation. The greatest increase in seasonal water deficit is predicted for the summer and autumn, and the present water surplus in the autumn and winter seasons will decrease (Table II). Because there is little deficit in winter and spring 


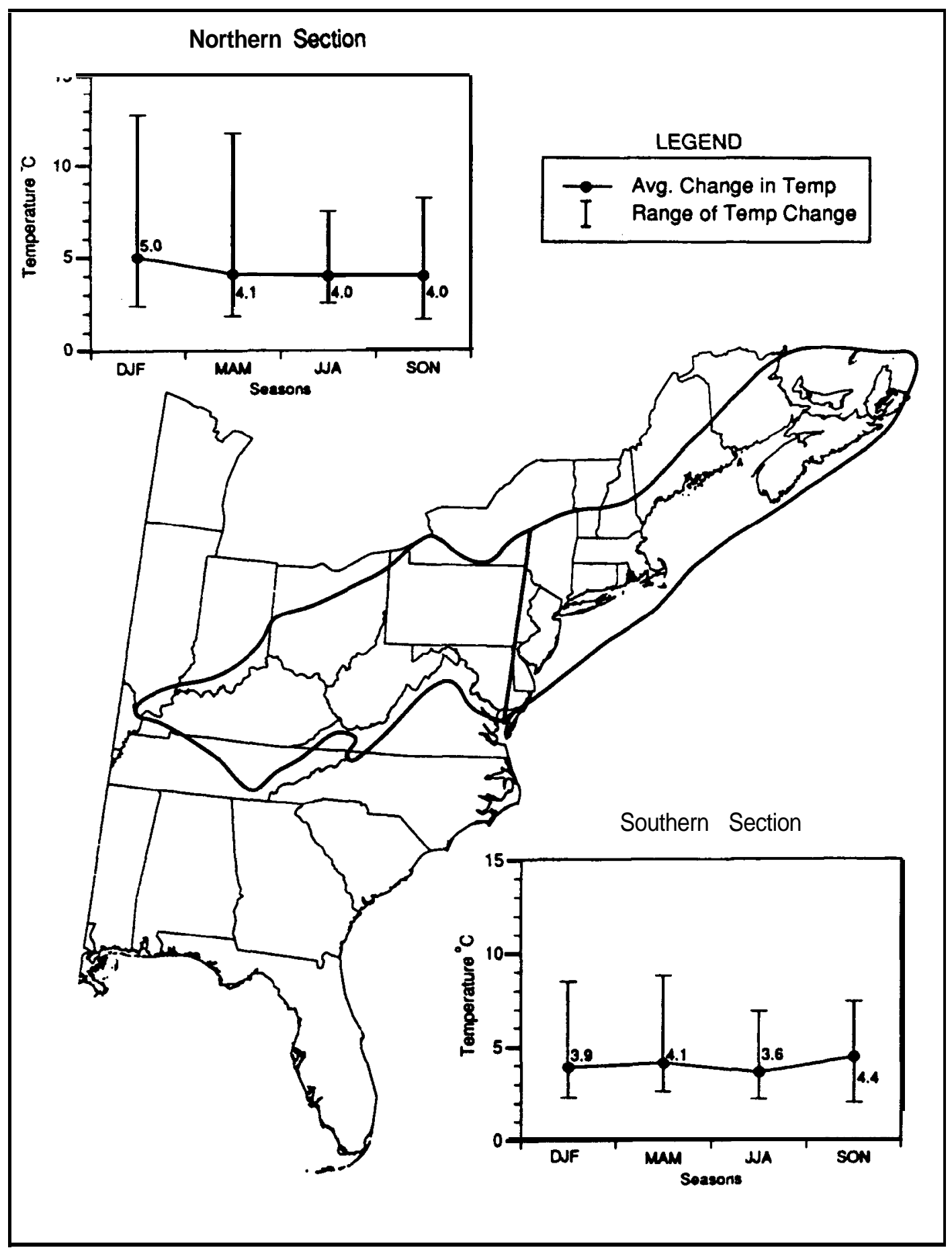

Figure 3. Projected mean change and range of change in air temperatun (" $\mathrm{C}$ ) for $2 \times \mathrm{CO}_{2}$ conditions in the northern and southern sections of the New England/Mid-Atlantic Region. Projections are most likely change generated from four GCMs and based on monthly averages. The vertical line within the region's boundaries separates the northern and southern sections for climatic analysis 


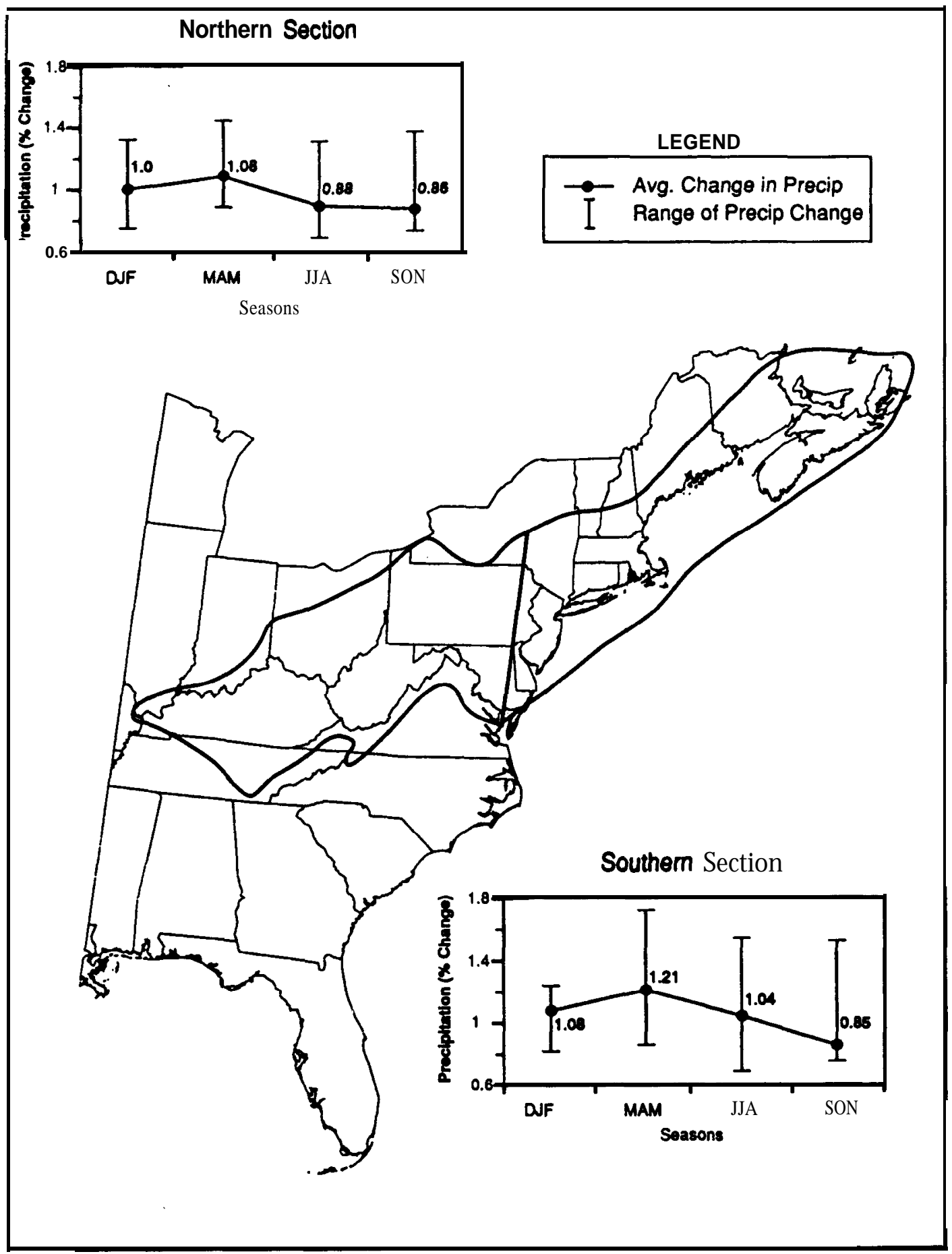

Figure 4. Projected mean change and range of change in precipitation per season for $2 \times \mathrm{CO}_{2}$ conditions in the northern and southern sections of the New England/Mid-Atlantic Region. Projections are most likely change generated from four GCMs and based on monthly averages. Values less than one indicate a decrease in precipitation and those exceeding one represent an increase. The vertical line within the region's boundaries separates the northern and southern sections for climatic analysis 
Table II. Likely seasonal changes in water surplus and deficit in the New England/Mid-Atlantic Region from present with a doubling of $\mathrm{CO}_{2}$. 'Most likely change' represents an estimated mean using data from all four GCMs (GISS. GFDL, OSU. UK) and the Thornthwaite-Mather water balance model (1955). 'Range of possible change' describes the range of the estimated means described previously. Months of the year are abbreviated and grouped into four seasons, beginning with winter

\begin{tabular}{lcccccccc}
\hline & \multicolumn{4}{c}{ Water deficit } & \multicolumn{3}{c}{ Water surplus } \\
\cline { 2 - 9 } & DJF & MAM & JJA & SON & DJF & MAM & JJA & SON \\
\hline $\begin{array}{l}\text { Present climate } \\
(\mathrm{mm})\end{array}$ & 0 & 0 & 9 & $<1$ & 310 & 177 & 4 & 9 \\
$\begin{array}{c}\text { Most likely change } \\
(\%)\end{array}$ & 0 & $+<1$ & +59 & +23 & -33 & -1 & -3 & -84 \\
$\begin{array}{c}\text { Range of possible. } \\
\text { change }(\%)\end{array}$ & 0 & 0 to +2 & +4 to $+106+1$ to $+24+7$ to $-48+7$ to -41 & $+\mathrm{I}$ to $-4+56$ to -85 \\
\hline
\end{tabular}

Table III. Projected mean change in total annual stream flow for the southern and northern sections of the New England/Mid-Atlantic Region under conditions of doubled $\mathrm{CO}_{2}$. Projections obtained as described in Table II

\begin{tabular}{|c|c|c|}
\hline & Southern section & Northern section \\
\hline Present climate $(\mathrm{mm})$ & 372 & 536 \\
\hline Most likely change $(\mathbf{\%})$ & -21 & -31 \\
\hline Range of possible change $(\mathbf{\%})$ & -32 to +6 & -32 to +4 \\
\hline
\end{tabular}

under present conditions, little change in this parameter is predicted under double $\mathrm{CO}_{2}$ conditions. A decrease in annual stream flow is also projected across all of the region (Table III); however, the greatest seasonal reductions should occur in autumn and winter (Table II).

A significant decrease in snow cover is also expected because of the increase in temperature associated with a doubling of $\mathrm{CO}_{2}$. Computations using expected temperature data suggest that essentially no snow cover will exist in the southern section of the area, while both the depth and duration of snow cover will be reduced in the northern section (Hodny and Mather, 1995). For example, a computation for the headwaters of the Delaware River in central New York shows a reduction in snow cover amount from $306 \mathrm{~mm}$ at present, to $90 \mathrm{~mm}$ under conditions of doubled $\mathrm{CO}_{2}$.

The character of the actual synoptic weather conditions that might exist in the region is more difficult to predict. If we assume, as many climatologists do, that warming in the Arctic will be greater than in the Tropics, this would suggest a decrease in the pole-equator temperature gradient. Normally, this would result in a reduced meridional flow of air masses according to the Rossby wave equation (fewer strong cold, dry air masses flowing southwards over the area as well as fewer warm, moist air masses flowing northwards) (Holton, 1992). The climate of the New England/Mid-Atlantic Region could become less variable in nature although this will probably be characterized by less rapid changes in daily weather rather than in reduced extremes. Summer convective thunderstorms will most likely increase in intensity (similar to those that now occur in the south-eastern US), and there is a suggestion that there may be longer time periods between thunderstorms (Henderson and Robinson, 1994; P. J. Robinson, personal communication). If this occurs, it may lead to greater variability in stream flow, especially in summer, with the smaller streams experiencing more flash flooding as well as longer periods of low flow than they exhibit at present. An increased number of forest fires is also possible owing to increased lightning strikes during periods of dry forest conditions (Price and Rind, 1994). 
Table IV. Rate of temperature increase (" $\mathrm{C}$ per 100 years) in selected cities, as excess over rural areas of comparable topography. Taken from Changnon (1992) and Landsberg (198 I)

\begin{tabular}{|c|c|c|}
\hline City & Winter & Summer \\
\hline Cleveland & 1.0 & 2.8 \\
\hline Boston & 1.6 & $2 \cdot 6$ \\
\hline Washington, D.C. & 0.9 & 2.4 \\
\hline
\end{tabular}

\section{URBAN CLIMATES}

Large metropolitan areas, which are common to this region, generate distinctive climates that, in some ways, may represent a microcosm of global climatic change (Oke, 1993). The magnitude, extremes and rate of change in urban air temperature and precipitation approximate that predicted to occur globally over the next 100 years in response to climatic change (Changnon, 1992). Annual average air temperatures in urban areas (cities with one million or more inhabitants) are $1-3^{\circ} \mathrm{C}$ warmer than nearby rural areas of comparable topography (Oke, 1993). On some nights, however, urban areas can be as much as $12^{\circ} \mathrm{C}$ warmer than nearby rural areas (Oke, 1993), and the magnitude of the urban heat island effect increases with population density (Oke, 1973, 1987). Consequently, average urban air temperatures have increased $2-3^{\circ} \mathrm{C}$ over the last 100 years as cities grew in size (Table IV; Changnon, 1992). Temperatures in urban areas over the last 100 years, however, have increased more during the summer than the winter (Table IV).

Urban climates differ in still other ways from rural or suburban climates. Large cities receive less snow because it is converted to rain, and more total precipitation often falls in the lee of the city (Oke, 1993). Furthermore, in at least some cities, summer rather than winter precipitation is increased (e.g. by $25 \%$ in St Louis and Chicago), predominantly because of heavy rainfall events (Changnon, 1992). Thus, the increase in intensity of summer convective storms as predicted for the New England/Mid-Atlantic Region has probably already occurred owing to local reasons in some large metropolitan areas. Greater amounts of runoff flow from urban watersheds owing to the impervious surfaces of asphalt and concrete. Also, in urban areas, solar radiation can be reduced by $1-25 \%$ because of air pollutants, and UV radiation can be reduced

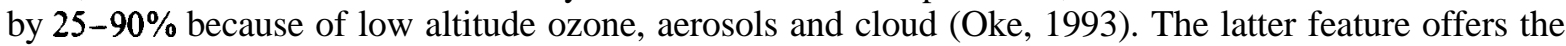
interesting possibility that aquatic systems in urban areas may serve as 'controls' for those located in rural areas and experiencing higher levels of UV-B radiation.

In summary, large metropolitan areas have experienced substantial climatic change over the last 100 150 years, and some of these changes may simulate those projected for a double $\mathrm{CO}_{2}$ atmosphere (Changnon, 1992; Oke, 1993). Warmer urban climates probably increase the heat content of freshwaters in multiple ways. For example, in urban areas, freshwater ecosystems may be warmed by runoff flowing over hot pavement. Historical records of water temperatures in urban areas could be used to examine hypotheses about warmed aquatic habitats. Aquatic ecosystems located in urban areas may provide 'natural laboratories' or analogues (e.g. Adrian et al., 1995) for measuring how these systems respond to climate change. Of course, using aquatic systems in this way will be challenging because. some urban aquatic systems receive increased atmospheric deposition and the water quality of urban runoff is often poor owing to road salt, lead and other contaminants.

\section{INTERACTIVE EFFECTS OF CLIMATE AND DIRECT HUMAN EFFECTS}

The direct effect of humans on aquatic ecosystems is likely to increase in this region over the next 50100 years as the human population of the region increases and climate changes. We present five examples of potential interactive effects between climate change and direct anthropogenic stressors. In these examples, we assume that warmer atmospheric temperatures will increase the temperatures of surface waters. If the 
frequency of forest fires increases in the northern section of the region (Price and Rind, 1994). the resultant enhanced exposure to wind could transfer the surface heat of lakes to deeper strata via mixing of the water column (Schindler et al., 1990). We also assume reductions in snowpack and stream flow, especially in autumn and winter, as predicted by Feddema and Mather (1992) and Hodny and Mather (1995). Although it is possible that the reductions in flow predicted here may be ameliorated by the anti-transpirent effect of $\mathrm{CO}_{2}$ enrichment. or the cooling effect of sulfate aerosols, humans may also divert water between basins to meet the water needs of expanding urban areas. Furthermore, the anti-transpirent effect of $\mathrm{CO}_{2}$ enrichment, observed in laboratory experiments using high rates of air flow, is not expected to occur on a regional scale in a forest (Graham et al., 1990). Thus, the assumption of flow reduction is reasonable.

\section{Estuarine Eutrophication}

Global climate change can influence estuaries in a variety of ways, including sea level rise, warming and changes in the salinity of coastal waters (Kennedy, 1990; Peterson et al., 1995). Climate change in the watersheds upstream of estuaries in the New England/Mid-Atlantic Region, however, may also affect primary production and eutrophication of estuarine waters. Eutrophication is a major problem in estuaries of this region, with excess nutrient inputs leading to enhanced rates of primary production and incidences of anoxia and hypoxia in bottom waters (National Research Council, 1993).

Nitrogen is the element that is most limiting to primary production in most estuaries of the northeastern US, and it is therefore the element most responsible for eutrophication (Howarth, 1988; National Research Council, 1993). Most of the nitrogen entering estuaries comes from non-point sources. In the New England/ Mid-Atlantic Region, only $25 \%$ of nitrogen inputs to the coastal zone comes from sewage, and $75 \%$ comes from non-point sources on land, principally from fertilizer and atmospheric deposition (Howarth et al., 1996). Climate change may affect this delivery of nitrogen to estuaries; the projected general decrease in water runoff and greatly decreased snowpack would be expected to result in more nitrogen retention in forests and agricultural lands, and less exported from land to the rivers and estuaries. Exports of organic carbon and phosphorus from land to estuaries would be likely to decline even more than nitrogen in a drier climate because these are largely particle bound, and erosion should decrease (Howarth et al., 1991). Of course, even if the climate becomes generally drier, a possible increase in the intensity of storms may increase erosion and consequent nutrient fluxes, as suggested by the modelling efforts of Howarth et al. (1991). None the less, most erosion in the Northeast occurs during the spring runoff period, and generally drier winters and springs are likely to result in less erosion.

A drier climate would also be expected to lead to changes in estuarine functioning owing to changes in hydrological mixing. The circulation patterns in an estuary are controlled by the interaction of tides and freshwater input from rivers, with additional influences from local topography. Salt wedge estuaries have high riverine inputs of water and relatively little tidal influence; these are the most stratified (Postma, 1980). Partially mixed and well-mixed estuaries have proportionately smaller inputs of freshwater from rivers, stronger tidal influences and are less stratified or not stratified at all (Postma, 1980). Tides are fairly strong in much of the New England/Mid-Atlantic Region, and, consequently, most of the estuaries in this region are either partially or well mixed. The projected decreases in freshwater runoff resulting from climatic change would be expected to drive estuaries towards being more mixed and less stratified. This, in turn, might affect primary production and eutrophication in several ways. First, the trapping of materials from both up-river and from coastal waters will tend to increase as estuaries become less stratified (Postma, 1980; Burton, 1988; Howarth et al., 1995); this might lead to increased respiration, nutrient recycling and, therefore, higher primary production. However, a counteracting tendency would be for greater light limitation of production in the more mixed estuaries; the more phytoplankton are mixed to a greater depth in the water column, the less light they experience and the lower their rate of net primary production (Malone et al., 1988; Cole et al., 199 1, 1992). Lessened stratification in estuaries also increases the rate of oxygen delivery into waters below the photic zone, decreasing problems from anoxia and hypoxia (Officer et al., 1984; Malone et al., 1988).

HYDROLOGICAL PROCESSES, VOL. 11, 925-947 (1997)

C 1997 by John Wiley \& Sons, Ltd. 
The effects of changes in circulation, stratification, primary production and oxygenation would have complex direct and indirect effects on the recruitment and exploitation of estuarine species. Many exploited populations are already under stress from habitat loss related to eutrophication and from excessive harvesting (Houde and Rutherford, 1993). The interactions of climate change, shifting patterns of human effects and eutrophication will most likely make the management of estuarine species even more difficult.

Overall, we expect that a drier climate in the New England/Mid-Atlantic Region would tend to lessen the problem of estuarine eutrophication as non-point nutrient inputs decrease, as light becomes more limiting to phytoplankton production and as more oxygen is advected into bottom waters. Direct support for this prediction comes from long time-series observations in Chesapeake Bay; the intensity of eutrophication and low oxygen levels there are positively related to the intensity of runoff in the spring (Malone et al., 1988). Future changes in land use and in pollutant loading, however, may be even more important (Howarth et al.. 1991). Regardless of climate scenario, we note that long-term records of climate and hydrological variability are available for many estuaries in this region. The potential for learning about the interactions between climate variability and estuarine dynamics has not been fully exploited (see Peterson et al., 1995).

\section{Acidification}

The magnitude and consequences of acidic deposition across the landscape are influenced by a variety of factors including the distribution and concentration of acids in wet and dry deposition, elevation, precipitation volume, vegetation type and biogeochemical processes that neutralize acidic deposition (Munson and Gherini, 1991; Ollinger et al., 1993). The effects of nitrogen are of particular interest, because this element is a nutrient and its forms and concentrations are sensitive to climatic conditions (Aber et al., 1989; Driscoll et al., 1989; Murdoch and Stoddard, 1992). Therefore, this discussion focuses primarily on the effects of climate change on nitrogen deposition and the cycling of nitrogen within watersheds.

It seems unlikely that the warmer, drier conditions projected for the New England/Mid-Atlantic Region will significantly influence the atmospheric deposition of nitrogen. In the Northeast, rain or snowfall occurs on average only $5 \%$ of the time. The remaining $95 \%$ of the time the landscape is exposed to inputs of dry deposition (Hicks and Shannon, 1979). Estimates of dry deposition for the region are only 15-25\% of the total deposition depending upon the model and geographical location (Ollinger et al., 1993). Thus, total deposition is largely dependent on the distribution, duration and volume of rainfall. If precipitation became more episodic (fewer, larger storms), there would most likely be some decrease in annual wet deposition that would be counterbalanced, only partly, by increases in annual dry deposition (Dr Gary Lovett, Institute of Ecosystem Studies, personal communication). As a result, atmospheric deposition of nitrogen would most likely decrease, but these changes would be small when compared with decreases anticipated from the 1990 Amendments of the Clean Air Act.

Although atmospheric deposition of nitrogen may not change much in response to climate change, nitrogen concentrations in freshwaters could change markedly if the cycling of nitrogen within the watershed is altered. For example, increased concentrations of atmospheric $\mathrm{CO}_{2}$ and air temperature during the growing season could enhance forest and microbial growth, resulting in increased sequestering of nutrients in terrestrial ecosystems (Peterson and Melillo, 1985; Schindler and Bayley, 1993). Increased assimilation of elements associated with forest growth should decrease solute leaching from forest soils to surface waters. However, 10 years of record in the Catskill Mountains, show that the highest annual average concentrations and yields of stream nitrate generally coincide with highest average annual air temperatures (Murdoch and Burns, 1995). With the exception of the water year 1990 (a year of high nitrogen deposition), stream nitrate concentrations cannot be attributed to changes in atmospheric deposition of nitrogen. The relationship between air temperature and stream nitrate concentrations and yields suggests that microbial mineralization of nitrogen in forest soils may have increased during warm years and exceeded rates of nitrogen assimilation by vegetation. This resulted in higher concentrations of nitrate in soil solutions and surface waters during warm years.

Interestingly, increases in air temperature could also change stream sulfate concentrations during the growing season. Sulfate reduction in ponded or slow-moving waters in the western Adirondacks can be 
enhanced by increasing air temperature, resulting in a decline in stream sulfate concentrations and an increase in acid-neutralizing capacity (ANC) (Burns, 1996). Likewise, lengthening the growing season would lengthen the period each year when sulfate reduction influences stream chemistry. The effect of increased ANC would be partly offset by attendant increases in dissolved organic carbon, which would, in turn, decrease light penetration and further alter biogeochemical processes (Cirmo and Driscoll, 1993; Burns, 1996).

The hydrological changes associated with a warmer climate will also affect biogeochemical processes and stream acidification. Returning to nitrogen cycling within the watershed, if the growing season is dry, soil moisture deficits could decrease both forest and microbial growth, and lower rates of denitrification. Thus, the effects of climate change on the nitrogen-induced acidity of surface waters will most likely be regulated by changes in processes within the watershed that retain nitrogen (e.g. forest growth) or release it to the atmosphere (e.g. denitrification) relative to processes that supply nitrogen (e.g. microbial mineralization).

Lower snowpack accumulation could also have a significant effect on stream hydrology and acidity in early spring. Snowmelt results in short-term acidification of surface waters, which may be critical to the survival of aquatic organisms. In northern areas of the Northeast as much as $50 \%$ of the annual discharge occurs during the months of March, April and May (Likens et al., 1977). Under warmer conditions, the magnitude of the peak flow would diminish and, consequently, so would the episodic acidification caused by spring meltwater.

Changes in stream acidification during spring snowmelt, however, will also depend on rates of soil mineralization during the dormant season, which is influenced by the duration and depth of soil freezing in winter. Shallow soils in the Catskill and Adirondack Mountains of New York often freeze during the late autumn, prior to snow cover, but generally thaw once the insulating barrier of the snowpack has developed (Rascher et al., 1987; Murdoch and Stoddard, 1992). Less accumulation of snowpack could result in more frequent or deeper freezing of the soil, reducing microbial activity during the winter. Deep freezing of soils would lyse root and microbial cells and enhance the release of labile nitrogen (Boutin and Robitaille, 1995). Presumably, this effect would diminish after a few years as the soil pools of available nitrogen become exhausted. However, if temperature increases during winter are high enough to limit soil frost, then microbial activity during the dormant season may exceed that of current conditions resulting in enhanced leaching of nutrients to surface waters.

Finally, less frequent but more severe summer storm events could result in episodes of increased stream acidity. Nitrogen appears to leach from forest soils to streams via a 'wash-out' process in which deposited or mineralized nitrate is flushed from the watershed during periods of increased runoff (Murdoch and Stoddard, 1992). If climate change causes less frequent, but larger rainfall events, the period of dry deposition and microbial nitrification between storms will increase, and this wash-out process may encourage larger pulses of nitrate to surface water. Likewise, in areas of high sulfate deposition, such as western Pennsylvania (Lynch and Corbett, 1989), sulfate pulses during episodic events could become more severe. With increased intensity of storms, dilution of basic cation concentrations during storm events should also increase (Schaefer $\boldsymbol{e} t$ al., 1990). Thus, increased acidity during storm events could occur under the projected warmer, drier conditions of the future. However, it is important to stress that these projections are dependent on changes in the seasonal distribution of precipitation and temperature, both of which are difficult to predict from current knowledge. If climate change results in an overall decrease in annual precipitation, but little change in storm frequency, episodic acidification should decrease.

\section{Biomagnifcation of Toxins}

The effects of increased water temperature and elevated concentrations of toxins have been measured separately in aquatic food-webs and are documented in the literature (Spry and Wiener, 1991; Havens and Hanazato, 1993; Moore and Folt, 1993). General predictions of the effect of climate change on the toxicity of aquatic contaminants, however, must be extrapolated from these separate findings, because the combined effects of temperature and toxicity are less well known (Moore and Folt, 1993). At the individual level, the 
metabolic rates of aquatic ectotherms will increase with increased temperatures. For those toxins taken up via ingestion or respiration (e.g. through the gills of fish), toxicity is likely to be enhanced at warmer temperatures, and organism tolerance to toxins may be diminished (Cairns et al., 1975; Connell and Miller, 1984). In addition, temperature-induced increases in ingestion or uptake of toxins that bioaccumulate (e.g. some metal toxins, chlorinated hydrocarbons) may result in more rapid bioaccumulation.

At the population and community levels, both increased temperature and toxins cause decreases in the body size of aquatic invertebrate communities (Havens and Hanazato, 1993; Moore and Folt, 1993). For example, zooplankton communities containing large cladocerans and copepods are usually more sensitive to a variety of toxins than those comprised of small cladocerans, copepod nauplii and rotifers. This phenomenon has been attributed to the greater sensitivity of larger organisms to toxicity (e.g. owing to enhanced permeability of the animal's cuticle during molting and the greater number of molts to maturity in large Daphniu; Gliwicz and Sieniawska, 1986) and to the release of some smaller taxa (e.g. rotifers) from competitive suppression by larger species (Papst and Boyer 1980; Day et al., 1987). At warmer temperatures, food-web structure over the long term will be largely dependent on the relative population growth rates of the most resilient species (Hanazato and Yasuno, 1987). Among algal communities, warmer water temperatures and longer periods of thermal stratification seem to favour large and inedible species (including green and blue-green taxa; Adrian et al., 1995). This, in combination with the loss of larger cladocerans, could have ecosystem-level effects, by decreasing the overall efficiency of carbon and energy transfer through lake foodwebs. Furthermore, elevated temperatures and toxins separately cause decreases in species diversity and richness in aquatic systems (Connell and Miller, 1984), and these stressors are likely to ellicit similar effects under the conditions of climate change (Stemberger and Lazorchak, 1994).

The numerous indirect effects of climate change may also alter the concentrations and bioavailability of toxins in aquatic systems. For example, a warmer climate may increase the rates of microbial degradation of toxins thereby reducing their concentrations in the environment. Conversely, predicted decreases of DOC associated with climate change may enhance the toxicity of some metals by decreasing concentrations of meta-binding ligands and increasing metal bioavailability. Lastly, hydrological alterations associated with climate change may also affect in situ concentrations of toxins in aquatic systems. Although reduced runoff could result in lower inputs of some contaminants into lakes, atmospherically transported toxins may actually increase in concentration owing to lower flushing rates of lakes and enhanced evaporation.

Mercury is an example of an atmospherically transported contaminant that is present in lakes throughout the developed and pristine areas of the New England/Mid-Atlantic Region (Driscoll et al., 1994). It is so widespread that fish tissue concentrations exceeding $\mathbf{0 . 2} \mathrm{ppm}$ mercury, a concentration indicative of an unhealthy or impaired ecosystem, have been observed in $30 \%$ of the lakes sampled in the Northeast by the EMAP programme (Yeardley and Lazorchak, 1994). The most toxic species, methyl mercury, occurs at such high concentrations in aquatic organisms in many lakes that it constitutes a major public health concern (Bloom, 1992; Driscoll et al., 1994). Bioaccumulation of mercury appears to be related to the age, size and habitat choice of fish (Driscoll et al., 1994; Spry and Wiener, 1991), underscoring the importance of diet to rates of bioaccumulation. Furthermore, greater body burdens of mercury higher in food chains provide evidence of biomagnification (Sorenson et al., 1990). Finally, mercury uptake increases with temperature (Boudou and Ribeyre, 1981).

The potential effects of climate change on mercury toxicity and propagation through aquatic food-webs will probably affect the contamination problem. Increased temperatures and metabolic rates will probably increase bioaccumulation and biomagnification rates, and thereby, increase levels of the contaminant in all organisms. Possible aiterations of food-webs (loss of large cladoceran grazers, increases in inedible foods) owing to increased temperatures and toxicity, however, may decrease the efficiency of energy and carbon transfer to higher trophic levels, thereby mitigating the transfer of mercury. Changes in the length of the food chain may also affect the degree of biomagnification. For example, PCB (polychlorinated biphenyls) concentrations in top predators seem to be greater where food chains are long; individuals of the same 
species in lakes with shorter food chains have lower body burdens (Rasmussen et al., 1990). This predicted scenario may also apply to mercury and other persistent toxins found in aquatic systems.

\section{Wetland desaturation}

Most of the wetlands of the region can be placed in one of three categories: bogs, minerotrophic wetlands (e.g. marshes, swamps and fens) and riverine wetlands. Bogs are primarily rain water fed. As such, their water status is controlled by the balance between precipitation and evapotranspiration. Minerotrophic wetlands, by contrast, are fed with surface and subsurface runoff from the surrounding watershed as well as directly from rain. Commonly, water enters such wetlands as groundwater, which has acquired a more mineral-rich chemical composition dictated by the characteristics of the surrounding soils (hence the term, minerotrophic). Riverine wetlands are a type of minerotrophic wetland whose water balance is strongly influenced by the presence of a river or stream, which may periodically flood the wetland. This hydrological categorization is adopted because the most important effects of projected climate change on wetlands in this region are likely to occur via changes in the water balance.

The climate scenario of most concern to wetlands is the scenario of decreased precipitation excess (i.e. a drier climate), exactly what is predicted for this region. Wetlands owe their existence to a high degree of water saturation of the soil; if this is eliminated, the wetland ceases to exist as a wetland. However, changes in temperature, the mixing ratio of atmospheric carbon dioxide, atmospheric acids and nutrients and the annual distribution of precipitation and evapotranspirational water demand are potentially significant to wetlands.

Intermittent desaturation of a wetland, and especially when limited to upper sediments, is a normal feature of wetland hydrology. However, numerous examples of intentional wetland drainage illustrate the effects of long-term desaturation. Soil oxidation accounts for most of the effects. As oxygen penetrates the sediment, microbes convert reduced chemical species, such as sulfide, ammonium and iron(II), to oxidized forms such as sulfate, nitrate and iron(III). As a result, sulfate and nitrate are leached and drainage waters and pore waters are acidified. Indeed, this release of mineral acids occurs not only as a chemical effect of long-term wetland drainage (Dasberg and Neumann, 1977), but can also be seen in the peaks in concentrations of sulfate and nitrate sometimes observed in late summer in temperate watersheds (e.g. Lazerte, 1993). Other effects include the subsidence of wetlands where the oxidation of organic material in the sediment exceeds the rate of deposition of new detrital organic material, and the loss of aquatic fauna as standing waters disappear from the wetland.

Bogs are probably the most susceptible of this region's wetlands to a drier climate. This is because bogs lack a strong mechanism to maintain water content and water chemistry in the face of increased evapotranspiration. At Thoreau's Bog in eastern Massachusetts, for example, approximately $70 \%$ of the annual precipitation is lost to evapotranspiration (Hemond, 1980). If annual evaporation were to increase by an amount equal to $20 \%$ of precipitation, an amount that lies within the range of climatic predictions for much of the New England/Mid-Atlantic Region, runoff would be decreased to one-third of its present value. A steady-state analysis of chemical budgets in this bog shows that those solute concentrations governed by hydrology (e.g. chloride) would then triple. Moreover, because annual variability could then result in frequent years when precipitation was less than evapotranspiration, the bog would probably experience episodes of extreme drying, with dramatic effects on soil oxidation and on the vegetation. It seems likely that this, and many other bogs in the New England/Mid-Atlantic Region, would not survive as bogs under the larger postulated changes of climate.

Minerotrophic wetlands, which are considerably more common than bogs in the New England/ Mid-Atlantic Region, except at the higher elevations and latitudes, should be more resilient than bogs in the face of climate change, mainly because, by definition, they receive water from a larger catchment than do bogs. Many such wetlands are in groundwater discharge areas, receiving inputs from both precipitation and groundwater aquifers. Consequently, their annual water output is usually much larger than that from bogs. Changes in evapotranspiration of such wetlands, therefore, represent a smaller influence on the water 
budget. and compensation for increased evapotranspiration in such minerotrophic wetlands could often be accomplished by a decrease in surface runoff from the wetland. It should be possible to predict the response of individual minerotrophic wetlands to drier conditions on the basis of present day water balance observations, including the relationship between water storage and the rate of surface water outflow (the stage-discharge curve) and the present water balance. The extent to which desaturation and loss of open water could occur is unknown, because water budgets and stage-discharge relationships have been established for very few wetlands in the region. However, minerotrophic wetlands should be much less affected than bogs.

Riverine wetlands represent perhaps the most resilient of the region's wetlands because of the regulating effect of stream and river stage. Such wetlands are least likely to be extensively desaturated unless river stage is lowered so much that the wetlands are no longer periodically flooded. Less dramatic effects than desaturation and soil oxidation may still result, however. A decrease in open water, caused by a drier climate, can limit wetland use by waterfowl, and possibly favour invasion by introduced plant species. Siltation, habitat fragmentation and eutrophication are common effects of human development. Under the dual impact of climate change and development, even wetlands that remain water saturated may suffer losses of biodiversity and become less valuable as wildlife habitat.

\section{Habitat Fragmentation and Fish Populations}

Increased water temperatures and a reduction in stream flow are the effects of climatic change that are most likely to affect stream communities within the region (Poff, 1992; Ward et al., 1990), and each of these variables is strongly influenced by land use patterns. For example, in agricultural areas, lower precipitation may trigger increased irrigation resulting in reduced stream flow (Adams et al., 1990). In forested areas, logging patterns influence instream temperatures through the direct effects of shading and of cover on overland water flow and groundwater temperatures. Reductions in radiative heating by vegetative cover may be particularly important in low-order streams, where the overhanging vegetation significantly reduces the magnitude and variation of the stream temperature compared with that of clear-cut regions (Burton and Likens, 1973; Ringler and Hall, 1975).

For stream-dwelling fish populations, temperature is a critical resource (sensu Magnuson et al., 1979), because it affects many important physiological and behavioural pathways that influence growth and survival. Yet, interactions between temperature, food ration, developmental stage, feeding, growth and survival are extremely complex (Elliott, 1982). Thus, predicting the range expansion and contraction of fish species in response to climatic change is difficult. Although the northern distributional limit of many fish species is limited by the fish's ability to store adequate energy for surviving periods of winter starvation (Shuter and Post, 1990), the southern limit of distribution is frequently determined by the fish's tolerance of maximum summer temperatures. Modest increases in stream temperature can increase growth rates of some species, while simultaneously exceeding the thermal maximum of others and driving them from that location. Species distributions may theoretically shift to the north (Shuter and Post, 1990) or to higher elevations (Meisner, 1990); but, shifts in species distributions require connecting streams with suitable habitat, which may not exist.

Stream species that are restricted to a narrow range of cooler temperatures may be particularly vulnerable to climate change. Such species, termed cold water stenotherms, include many stream insects (Vannote and Sweeney, 1980; Sweeney et al., 1992) and a number of fish species that are recreationally important (e.g. salmonids; Elliott, 1982). The potential effects of a warmer climate on cold water populations in the region are perhaps best illustrated by examining predictions for brook trout (Salvelinus fontinalis). Meisner (1990) projects that a $3.8^{\circ} \mathrm{C}$ increase in mean annual temperature would reduce the area suitable for brook trout, primarily in coastal and low elevation areas of their present distribution in the region. Distributions may be further reduced if human activities and vegetational changes result in increased fragmentation of forested areas within watersheds and riparian habitats. Such forest fragmentation could further increase stream temperatures. This same temperature change, however, may result in increased vigour for populations 
in high elevation and northern portions of the range, because the length of the growing season would increase in these areas (Meisner, 1990).

In the Appalachian Mountains of Virginia and West Virginia, native brook trout are near the southern edge of their distribution in eastern North America (MacCrimmon and Campbell, 1969). Trout distributions in Virginia are already fragmented and essentially restricted to first- to third-order streams (Flebbe, 1994). Here, elevation and latitude interact to provide an acceptable temperature regime for brook, introduced rainbow (Oncorhynchus mykiss) and brown trout (Salmo trutta) (Meisner, 1990; Flebbe, 1994). Under the GISS warming scenario, the theoretical lower elevation for brook trout occurrence would increase about $700 \mathrm{~m}$ for most of Virginia (Meisner, 1990). Because few streams in Virginia are found at these higher elevations, loss of brook trout streams in Virginia would be considerable (Flebbe, 1993). Unreliable summer flows already occur in many high elevation Virginia streams, and the reduced flows predicted by climate change models (Poff, 1992) for the region would further restrict the available trout habitat. Finally, the distribution of remaining brook trout streams would be seriously fragmented as brook trout disappear from lower elevation streams and remain only in isolated patches at the uppermost elevations. Human intervention, in the form of stocking, may be required to maintain fragmented headwater populations in the face of localized extinctions, sometimes exacerbated by anglers.

\section{RECOMMENDATIONS}

Clearly, the dual stressors of climate change and direct human impact have the potential to transform aquatic ecosystems dramatically by altering stream flows and nutrient cycles, eliminating habitats (e.g. bogs) and changing community structure. To detect, understand and manage these transformations, both monitoring and research will be necessary because these two approaches complement each other. Welldesigned monitoring programmes can help to direct research efforts and provide useful information for interpreting or generalizing from experimental results. Likewise, experiments may reveal new parameters necessary for detecting perturbations via monitoring. Our specific recommendations address both climate change and direct human effects on freshwater ecosystems.

\section{Monitoring}

1. Extend and improve data on the distribution, abundance and effect of anthropogenic stressors (non-point pollution) within the region. Current data are often substandard for the reasons previously mentioned, Monitoring efforts between state, federal and academic institutions should be better coordinated within the region, meet high standards (e.g. employ statistically valid sampling design) and the data should be disseminated widely.

2. Improve scientific knowledge regarding the contemporary distribution and abundance of aquatic species in the $\mathrm{New}$ England/Mid-Atlantic Region. Climate change, coupled with either continued or increasing anthropogenic stress, has the potential to alter enormously the distribution and abundance of native species in this region. Yet, knowledge of the present distribution and abundance of aquatic species in this region, as in other areas of North America, is poor (Schindler, 1989). Such baseline information is essential for assessing the biotic effects of climate change and for effective management of aquatic resources. It can be argued that net species diversity may not decline in response to climate change, because species loss may be balanced by the introduction of exotics or by species from the Southeast expanding their ranges northwards. For example, in the Hudson River drainage, total molluscan species richness has not changed substantially over the past 150 years, because species introductions have offset extinctions (Strayer, 1987). Nevertheless, considerable ecological and economic dislocation has resulted from widespread changes in the abundance and distribution of species (US Congress, Office of Technology Assessment, 1993). Intervention by management agencies to restore, protect or replace lost species (e.g. Atlantic salmon), as often demanded by the public, can lead to the expansion of government expense and regulation. Research on the interactions between species changes, human activities and management regulation will be required to understand the 
actual ecological and economic costs of altered species distributions and abundances. Finally, conserving the region's present biodiversity is essential to maintain species valuable for restoring and rehabilitating degraded ecosystems.

\section{Future Research}

1. Establish a research centre ( $s$ ) where field studies designed to understand interactions between freshwater ecosystems and climate change can be conducted. Although three LTER (Long-Term Ecological Research) sites are located within this region (Hubbard Brook, Harvard Forest and Virginia Coastal Reserve), the potential for major large-scale experiments on freshwater systems is primarily limited to small streams at these locations. This region, however, contains a plethora of lakes and reservoirs, wetlands, and large rivers, some of which provide the entire potable water supply for major metropolitan areas. For example, reservoirs or rivers, rather than wells, supply all of the potable water for the millions of residents of New York City, Boston and Washington D.C. (Schwarz and Dillard, 1990). Managers of such urban water systems warn that $10-$ $20 \%$ reductions in runoff and longer hot spells associated with climate change could require costly expansion of supplies as well as treatment facilities to remove contaminants that form more readily in the presence of high temperatures and chlorine (e.g. trichloromethane; Schwarz and Dillard, 1990). Despite the potential effects of climate change on the quantity and quality of surface waters of the region, there is not one scientific institute devoted to freshwater research on a scale commensurate with the significance of the resource.

2. Project the future distribution, activities and direct effects of humans within the region. Humans are abundant in this region and their response to climate change will probably greatly influence the structure and functioning of freshwater ecosystems. For example, palaeolimnological studies conducted in Vermont and Connecticut have revealed how major historical shifts in human land use greatly affected some freshwater ecosystems of the region (Brugam, 1978; Engstrom et al., 1985). Because socio-economic factors largely drove these shifts in land use (Whitney, 1994; Foster, 1995), interdisciplinary studies integrating the fields of ecology, sociology and economics will be needed to identify the future distribution, activities and effects of humans as climate changes. Pertinent questions include: what proportion of humans will migrate from the congested coast into upstream forested watersheds in response to changing economics, a deteriorating climate in coastal urban areas or an increase in sea-level? What consequences will such migrations have for freshwater systems?

3. Develop mathematical analyses, experimental designs and aquatic indicators that distinguish between climatic and anthropogenic effects on aquatic systems. A mathematical technique called double mass analysis is used by hydrologists to separate the effects of climate from land use activities (e.g. conversion of forest to farmland) on the discharge patterns of rivers (e.g. Verry, 1986). It may be possible to develop similar techniques for separating the effects of climate and land use activities on the processes of aquatic ecosystems. Experimental designs comparing climatically induced changes of community and ecosystem processes among habitats differentially affected by humans should be employed. For example, replicate urban and rural plots over latitudinal or altitudinal gradients might be used. Reductions in flow of headwater streams or lengthened drying of ephemeral ponds may provide indicators or early signals of climatic warming. Such hydrological indicators would be particularly useful for this region because they are less likely to be affected by direct anthropogenic stressors than biotic or chemical indicators. At present, no monitoring of these small aquatic habitats is required of states by the Clean Water Act of 1972 (US EPA, 1994).

4. Develop and refine projections of climate variability such that the magnitude, frequency and seasonal timing of extreme events can beforecasted. Inherent in this recommendation is the assumption that freshwater ecosystems will be more greatly affected by changes in the magnitude or frequency of extreme events than changes in the mean. Tests of this assumption, however, are necessary (Grimm, 1993).

5. Describe, quantitatively, the flux of materials (sediments, nutrients, metals) from watersheds characterized by a mosaic of land uses. Most of the anthropogenic stressors affecting the freshwater ecosystems of this region are constituents of non-point pollution. Consequently, understanding how the mobility of these 
constituents is affected by multiple land uses, as well as altered patterns of rainfall and runoff, is necessary for protecting freshwaters.

Clearly, the direct effect of humans within this region, coupled with the effects of climate change, have the potential to alter aquatic ecosystems and their watersheds to an extent equalling, or surpassing, that which occurred in the late eighteenth and nineteenth centuries. Historical records and palaeoecological studies demonstrate that two major historical transformations of the land and aquatic ecosystems have taken place in this region. The first was deforestation coupled with intensive agriculture. That was followed by farm abandonment and reforestation, which allowed recovery of some aquatic systems. A third major transformation has begun in the coastal areas of this region and is rapidly expanding inland. It is the urbanization of landscapes, involving the interactive effects of urban-induced climate change, pollution and radical physical alteration of hydrological systems. This most radical of the three anthropogenic transformations, coupled with regional climatic change, portends aquatic ecosystems of completely unknown structure and function.

\section{ACKNOWLEDGEMENTS}

The authors are indebted to the US Environmental Protection Agency, the US Geological Survey, the American Society of Limnology and Oceanography and the North American Benthological Society for sponsoring and organizing the symposium on the effects of climate change on freshwater ecosystems. The interdisciplinary approach taken promoted the exchange of knowledge and the development of ideas presented here. We also thank Steve Paulsen, Richard Stemberger, Roger Yeardley and Kevin Summers for sharing unpublished data from the EMAP-SW programme funded by the US EPA; Timothy R. Oke for stimulating ideas regarding urban climates; David Foster and Charlie Cogbill for manuscripts and references on historical land use patterns; Laura Conkey who provided maps of human demography; and Ralph Tiner and Barbara Bedford for information regarding the abundance and distribution of wetlands. Finally, the first author is especially grateful for the expert assistance of Ms Lisa Brainard and Irene Laursen, librarians at Wellesley College, who rapidly obtained numerous government documents, maps and publications.

\section{REFERENCES}

Aber, J. D.. Nadelhoffer, K. J.. Steudler, P., and Melillo, J. M. 1989. 'Nitrogen saturation in northern forest ecosystems', BioScience. 39, 378-386.

Adams, R. M.. Rosenzweig, C., Peart, R. M., Richie, J. T., McCarl, B. A. Glyer, D., Curry, R. B., Jones, J. W., Boote, K. J., and Allen, L. H. 1990. 'Global climate change and US agriculture', Nature, 345, 219-224.

Adrian, R., Deneke, R., Mischke, U.., Stellmacher, R., and Lederer, P. 1995. 'A long term study of the Heiligensee (1975-1992): evidence for effects of climatic change on the dynamics of eutrophied lake ecosystems', Arch. Hydrobiol., 133, 3 15-337.

Alampi, G. 1994. Gale State Rankings Reporter. Gale Research Inc., Detroit. p. 1657.

Ashizawa, D. and Cole. J. J. 1994. 'Long-term temperature trends of the Hudson River: a study of the historical data', Estuaries, 17. $166-171$.

Bloom. N. S. 1992. 'On the chemical form of mercury in edible fish and marine invertebrate tissue', Can. J.Fish. Aquat.Sci., 49, $1010-1017$.

Bosch. J. M. and Hewlett. J. D. 1982. 'A review of catchment experiments to determine the effect of vegetation changes on water yield and evaporation', J. Hydrol.. 55, 3-23.

Boudou, A. and Ribeyre, F. 1981. 'Comparative study of the trophic transfer of two mercury compounds $-\mathrm{HgCl}_{2}$ and $\mathrm{CH}_{3} \mathrm{HgCl}$ - between Chlorella vulgaris and Daphnia magna. Influence of temperature'. Bull. Environ. Contam. Toxicol.. 27.624-629.

Boutin, R. and Robitaille, G. 1995. 'Increased soil nitrate-losses under mature sugar maple trees affected by experimentally induced deep frost', Can. J. For. Res., 25, 588-602.

Bradley. R. S., Eischeid, J. K., and Ives.P. T. 1987. 'The climate of Amherst, Massachusetts', Conrriburion No. 50. Department of Geology \& Geography, University of Massachusetts, Amherst. p. 108.

Bruaam. R. B. 1978. 'Pollen indicators of land-use change in southern Connecticut'. Quat Res,. 9. 349-362.

Brush.G. S. 1986. 'Geology and paleoecology of Chesapeake Bay: a long-term monitoring tool for management', J. Washington Acad Sri., 76. 146- 160.

Burns, D. A. 1996. 'The effects of liming an Adirondack lake watershed on downstream water chemistry', Biogeochemisrry, 32, 339-362.

Burton. J. D. 1988. 'Riverborne materials and the continent-ocean interface', in Lermand, A. and Meybeck. M. (Eds), Physical and Chemical Weathering in Geochemicul Cycles. Kluwer, Dordrecht. pp. 299-321.

HYDROLOGICAL PROCESSES, VOL. 11, 925-947 (1997)

(C) 1997 by John Wiley \& Sons, Ltd. 
Burton. T. M. and Likens. G. E. 1973. 'Effects of strip-cutting on stream temperatures in the Hubbard Brook Experimental Forest. New Hampshire'. BioScience. 23. 433-435.

Cairns. J.. Heath. A.G.. and Parker. B. C. 1975. 'The effects of temperature upon the toxicity of chemicals to aquatic organisms'. Hidrobiologia. 47. 135- I7 1.

Changnon. S A. 1992. 'Inadvertent weather modification in urban areas: lessons for global climate change', Bull. Am. Meteorol.Soc.. 73. $619-627$.

Cirmo. C. P. and Driscoll. C. T. 1993. 'Beaver pond biogeochemistry: Acid-neutralizing capacity generation in a headwater wetland', Weilands 13. 277-291

Cole. J. J.. Caraco. N. F., and Peierls. B. L. 1991. 'Phytoplankton primary production in the tidal, freshwater Hudson River, New York (CSA)'. Verh. Int. Ver. Limnol., 24. 1715-1719.

Cole. J. J., Caraco. N. F.. and Peierls, B. L. 1992. 'Can phytoplankton maintain a positive carbon balance in a turbid, freshwater, tidal estuary?‘. Limnol. Oceanogr.. 37, 1608-1617.

Connell. D. W. and Miller, G. J. 1984. Chemistry and Ecotoxicology of Pollution. John Wiley and Sons, Inc., New York. pp. 288-332.

Cosby. B. J.. Ryan, P. F.. Webb, J. R., Hornberger, G. M., and Galloway, J. N. 1991. 'Mountains of Western Virginia', in Charles, D. F. (Ed.). Acidic Deposition and Aquatic Ecosystems: Regional Case Studies. Springer-Verlag, New York. pp. 297-318.

Culliton. T. J.. Warren, M. A., and Godspeed, T. R. 1990. '50 years of population changes along the nation's coasts 1960-2010', Technical Report. US Department of Commerce, NOAA, Strategic Assessment Branch, Rockville, Maryland.

Dahl, T. E. 1990. 'Wetland losses in the United States 1780's to 1980's', Report. US Department of the Interior, Fish and Wildlife Service. Washington. D.C.

Dasberg. S. and Neumann. S. P. 1977. 'Peat hydrology in the Hula Basin, Israel: I. Properties of peat', J.Hydrol., 32, 219-239.

Day, K. E., Kaushik. N. K.. and Solomon, K. R. 1987. 'Impact of fenvalerate on enclosed freshwater planktonic communities and on in situ rates of filtration of zooplankton', Can. J. Fish. Aquat. Sci., 44, 1714-1728.

Driscoll. C. T., Schaefer, D. A., Molot, L. A.. and Dillon, P. J. 1989. 'Summary of North American data', in Malanchuk, J. L. and Nilsson. J. (Eds). The Role of Nitrogen in the Acidification of Soils and Surface Waters. Nordic Council of Ministers, Copenhagen. pp. 6. $1-6.45$.

Driscoll, C. T.. Newton. R. M.. Gubala, C. P., Baker, J. P. and Christensen, S. W. 1991. 'Adirondack Mountains', in Charles. D. F. (Ed.). Acidic Deposition and Aquatic Ecosystems: Regional Case Studies. Springer-Verlag, New York. pp. 133-202.

Driscoll. C. T., Yan, C.. Schofield. C. L., Munson, R., and Holsapple. J. 1994. 'The mercury cycle and fish in the Adirondack Lakes', Environ. Sci. Technol.. 28.136-143.

Elliott. J. M. 1982. 'The effects of temperature and ration size on the growth and energetics of salmonids in captivity', Comp. Biochem. Physiol., 73. 8 l-9 1 .

Engstrom. D. R., Swain, E. B.. and Kingston, J. C. 1985. 'A palaeolimnological record of human disturbance from Harvey's Lake, Vermont: geochemistry, pigments and diatoms', Freshwat.Biol.,15, 261-288.

Feddema. J. J. and Mather. J. R. 1992. 'Hydrological impacts of global warming over the United States', in Majumdar, S. J., Kalkstein, L. S.. Yarnal, B. M., Miller, E. W. and Rosenfeld, L. M. (Eds), Global Climate Change: Implications. Challenges and Mitigation Measures. Pennsylvania Academy of Science, Easton, Pennsylvania. pp. 50-62.

Flebbe. P. A. 1993. 'Comment on Meisner (1990): effect of climate warming on the southern margins of the native range of brook trout, Salvelinus fontinalis', Can. J. Fish. Aquat. Sci., 50, 883-884.

Flebbe. P. 1994. 'A regional view of the margin: salmonid abundance and distribution in the southern Apalachian Mountains of North Carolina and Virginia'. Trans. Am. Fish. Soc., 123. 657-667.

Foster, D. 1992. 'Land-use history (1730- 1990) and vegetation dynamics in central New England, USA', J. Ecol.,80, 753-772.

Foster, D. 1995. 'Land-use history and four hundred years of vegetation change in New England', in Turner, B. L., II, Sal, A. G., Bernaldez. F. G., and di Castri, F. (Eds), Global Land Use Change: A Perspectiw from the Columbian Encounter. Scientific Research Council of Spain, Madrid, Spain. pp. 253-339.

Gliwicz. W. Z. and Sieniawska, A. 1986. 'Filtering activity of Daphnia in low concentrations of a pesticide', Limnol. Oceanogr., $31.1132-1137$

Graham, R. L., Turner, M. G., and Dale, V. H. 1990. 'How increasing $\mathbf{C O}_{2}$ and climate change affect forests'. Bioscience, 40, 575-587.

Greeley, W. B. 1925. 'The relation of geography to timber supply', Econ. Geogr., 1, 1-4.

Grimm, N. B. 1993. 'Implications of climate change for stream communities', in Kareiva, P. M.. Kingsolver, J. G., and Huey, R. B. (Eds), Biotic Interactions and Global Change. Sinauer Associates Inc., Sunderland, Massachusetts. pp. 293-3 14.

Hamburg. S. P. and Cogbill, C. V. 1988. 'Historical decline of red spruce populations and climatic warming', Nature, $331.428-431$.

Hanazato. T. and Yasuno. M. 1987. 'Effects of carbamate insecticide, carbaryl, on the summer phyto- and zooplankton communities in ponds', Environ. Pollut., 48,145-159.

Hansen. J.. Fung, I., Lacis, A., Lebedeff, S., Rind, S., Ruedy, R., Russell, G., and Stone, P. 1988. 'Global climate changes as forecast by the GISS 3-D model', J. Geophys. Res., 93, 9342-9364.

Havens, K. E. and Hanazato, T. 1993. 'Zooplankton community responses to chemical stressors: a comparison of results from acidification and Desticide contamination research', Environ. Pollut., 82, 277-288.

Hayes, J. T.1991. 'Global climate change and water resources', in Wyman, R. L. (Ed.), Global Climate Change and Life on Earth. Chapman and Hall, Inc., New York. pp. 18-42.

Hemond. H. F. 1980. 'Biogeochemistry of Thoreau's Bog', Ecol. Monogr., s0, 507-526.

Henderson. K. G. and Robinson, P. J. 1994. 'Relationships between the Pacific/North American teleconnection patterns and precipitation events in the south-eastern USA', Int. J. Clim., 14, 307-323.

Hick, B. B. and Shannon, J. D. 1979. 'A method for modelling the deposition of sulfur by precipitation over regional scales', J. Appl. Meteorol.. 18.1415- 1420. 
Hodny. J. W. and Mather. J. R. 1995. Climate change and the water resources of Delmarva and the Delaware River basin'. Puhl. Climatol., Lob. Climasol. 48.1-87.

Holton. J. R. 1992. An Introduction to Dynamic Meterology. Academic Press. San Dtego. p. 51 I.

Houde. E. D. and Rutherford. E. S. 1993. 'Recent trends in estuarine fisheries: predictions of fish production and yield'. Estuaries. 16. $161-176$

Howarth. R. W. 1988. 'Nutrient limitation of net primary production in marine ecosystems'. Annu. Rev. Ecol.Syst., 19, 89-I IO.

Howarth. R. W.. Fruci, J. R., and Sherman, D. 1991. 'Inputs of sediment and carbon to an estuarine ecosystem: influence of land use'. Ecol. Appl.. 1. 27-39.

Howarth. R. W., Jensen. H., Marino. R., and Postma. H. M. 1995. 'Transport and processing of phosphorus in near-shore and oceanic waters'. in Tiessen, H. (Ed.). Phosphorus in the Global Environment, SCOPE \#54. Wiley \& Sons, Chichester. pp. 323-345.

Howarth, R. W.. Billen, G.. Swaney, D., Townsend, A.. Jaworski, N, Lajtha, K., Downing, J. A., Elmgren, R., Caraco, N., Jordan, T.. Berendese. F., Freney, J., Kudeyarov. V.. Murdoch, P.. and Zhao-hang, Zhu, 1996. 'Regional nitrogen budgets and riverine N and P fluxes for the drainages to the North Atlantic Ocean: natural and human influences', in Howarth. R. W. (Ed.), Nitrogen Cycling in the North Atlantic Oceans and its Watersheds. Kluwer, Boston. pp. 75- 140.

Husar. R. B., Sullivan, T. J., and Charles, D. F. 1991. 'Historical trends in atmospheric sulfur deposition and methods for assessing long-term trends in surface-water chemistry'. in Charles, D. F. (Ed.), Acidic Deposition and Aquatic Ecosystems: Regional Case Studies. Springer-Verlag. New York. pp. 65-82.

Jones, P. D. and Bradley, R. S. 1992. 'Climatic variations in the longest instrumental record', in Bradley, R. S. and Jones. P. D. (Eds), Climate Since A.D. 1500 . Routledge. London. pp. 246-268.

Kennedy. V. S. 1990. 'Anticipated effects of climate change on estuarine and coastal fisheries'. Fisheries, 15, 16-24.

Landsberg, H. E. 1981. 'The urban climate', Int. Geophys. Ser., 28, 1-275.

Lazerte. B. D. 1993. 'The impact of drought and acidification on the chemical exports from a minerotrophic conifer swamp', Biogeochemistry, 13, 153-175.

Leavesley, G. H., Turner, K., D'Agnese, F. A., and McKnight, D. 1997. 'Regional delineation of North America for the assessment of freshwater ecosystems and climate change', Hydrol. Process., 11, 819-824.

Lee, R. 1980. Forest Hydrology. Columbia University Press, New York.

Likens. G. E., Bormann, F. H., Pierce, R. S., Eaton, J. S., and Johnson, N. M. 1977. Biogeochemistry of a Forested Ecosystem. SpringerVerlag, New York. p. 146.

Lynch. J. A. and Corbett, E. S. 1989. 'Hydrologic control of sulfate mobility in a forested watershed', Wat. Resow. Res., 25, $1695-1703$.

MacCrimmon. H. R. and Campbell, J. S. 1969. 'World distribution of brook trout, Salvelinus fontinalis', J. Fish. Res. Bd Can.,26.1699-1725.

Magnuson. J. J., Crowder, L. B., and Medvick, P. A. 1979. 'Temperature as an ecological resource', Am. Zoo/., 19, 331-343.

Malone. T. C., Crocker. L. H., Pike, S. E., and Wendler, B. W. 1988. 'Influence of river flow on the dynamics of phytoplankton production in a partially stratified estuary', Mar. Ecol. Prog. Ser., 48, 235-249.

Manabe. S. and Wetherald, R. T. 1987. 'Large-scale changes of soil wetness induced by an increase in atmospheric carbon dioxide', J. Atmos. Sci.. 44. 1211-1235.

Meisner, J. D. 1990. 'Effect of climatic warming on the southern margin of the native range of brook trout, Salvelinus fontinalis', Can. J. Fish. Aquot. Sci., 47, 1065- 1070.

Miller, E. W. and Miller, R. M. 1992. Water Quality and Availability: a Reference Handbook. ABC-CLIO, Inc. Santa Barbara, California. p. 430.

Moore, M. V. and Folt, C. L. 1993. 'Zooplankton body size and community structure: effects of thermal and toxicant stress', Trends Ecol. Evol., 8, 178-183.

Morgan, K. O.. Morgan, S., and Quitno, N. 1993. Stare Rankings 199.3. Morgan Quitno Corporation, Lawrence, Kansas. p. 511.

Munson, R. K. and Gherini, S. A. 1991. 'Processes influencing surface water acidification', in Charles, D. F. (Ed.), Acid Deposition and Aquatic Ecosystems: Regional Case Studies. Springer-Verlag. New York. pp. 9-34.

Murdoch. P. S. 1991. 'Chemical budgets and stream chemistry dynamics of a headwater stream in the Catskill Mountains of New York, October I. 1983 through September 30, 1985’. US Geological Survey Water Resources Investigation Report 88-4035. USGS, Albany, New York. p. 66

Murdoch. P. S. and Bums, D. A. 1995. 'Effect ofclimate on nitrate concentrations in watersheds of the Catskill Mountains, New York', in Gvennfelt, P., Rodhe, H., Thörnelöf, E., and Wisniewski, J. (Eds), Acid Reign '95, Proceedings, Conference on Acid Deposition, Gotenborg. Sweden, 26-30 June, 1995. Kluwer Academic Publishers, Amsterdam. p. 357.

Murdoch. P. S. and Stoddard. J. L. 1992. 'The role of nitrate in the acidification of streams in the Catskill Mountains of New York', War. Resour. Res. 28, 2707-2720.

National Research Council, 1993. ManagingWastewater in Coastal Urban Areas. National Academy Press, Washington, D.C. p. 477.

Officer. C. B.. Biggs. R. B.. Taft, J. L.. Cronin. L. E., Tyler, M. A., and Boynton, W. R. 1984. 'Chesapeake Bay anoxia: origins, development. and significance', Science, 223. 22-27.

Oke. T. R. 1973. 'City size and the urban heat island', Atmos. Environ., 7, 769-779.

Oke. T. R. 1987. Boundary Laver Climates, 2nd edn. Methuen, London, p. 435.

Oke. T. R. 1993. 'Global change and urban climates', Proc. 13th Internat. Congress Biometeorol., 1, 123-134.

Ollinner. S. V... Aber. J. D.. Lovett. G. M.. Millham. S. E.. Lathrop. R. G., and Ellis, J. M. 1993. 'A spatial model of atmospheric deposition for the forested northeastern United States', Ecol.Appl., 3, 459-472.

Papst. M. H. and Boyer, M. G. 1980. 'Effects of two organophosphorus insecticides on the chlorophyll $\boldsymbol{a}$ and pheopigment concentrations of standing ponds', Hydrobiologia, 69, 245-250.

Paulsen. S. G., Larsen, D. P., Kaufman, P., Whittier, T. R., Baker, J. R., Peck, D. V., McGue. J., Hughes, R. M., McMullen, D., Stevens. D.. Stoddard, J. L., Lazorchak, J. M., Kinney, W., Selle, A. R., and Hjort. R. 1991. 'EMAP-surface waters monitoring and research strategy fiscal year 1991',EPA/600/3-9J/022. US EPA, Corvallis, Oregon. p. 184. 
Pennsylvania Environmental Resources Department, 1994. Water Quality Assessment. 305 (b) Report. Water Quality Management Bureau. Harrisburg. Pennsylvania. p. 186.

Peterson. B. J and Melillo. J. M. 1985. 'The potential storage of carbon caused by eutrophication of the biosphere'. Tellus. 37B. $117-127$.

Peterson. D.. Cayan. D.. DiLeo. J.. Noble. M.. and Dettinger. M. 1995. 'The role ofclimate in estuarine variability'. Am Sci.. 83. 58-67.

Poff.N L. 1992. 'Regional hydrologic response to climate change: an ecological perspective'. in Firth. P. and Fisher. S. G. (Eds), Global Climate Change and Freshivater Ecosistems. Springer-Verlag, New York. pp. 88-115.

Postma. H. 1980. 'Sediment transport and sedimentation,' in Olausson, E. and Cato. I. (Eds), Chemistry and Biogeochemisty of Estuaries. Wiley, Chichester. pp. 153- 187.

Price, C. and Rind. D. 1994. 'The impact of a $2 \times \mathrm{CO}$, climate on lightning-caused fires'. J Clim. 7. 1484- 1494.

Rascher. C. M.. Driscoll. C. T.. and Peters, N. E. 1987. 'Concentration and flux of solutes from snow and forest floor during snowmelt in the west-central Adirondack region of New York', Biogeochemistry, 3. 209-224.

Rasmussen. J. B.. Rowan. D. J.. Lean, D. R. S.. and Carey. J. H. 1990. 'Food chain structure in Ontario Lakes determines PCB levels in lake trout (Salvelinus namavcush) and other pelagic fish', Can.J. Fish. Aquat. Sci.. 47, 2030-2038.

Ringler. N. H. and Hall. J. D. 1975. 'Effects of logging on water temperature and dissolved oxygen in spawning beds'. Trans. Am. Fish. Soc.. $1.111-121$

Robinson. W. F. 1988. Mountain New England - Life Past and Present. Little, Brown and Co., Boston. p. 206.

Schaefer, D. A.. Driscoll. C. T., van Dreason. R., and C. P. Yatsko. 1990. 'The episodic acidification of Adirondack lakes during snowmelt', War. Resow. Res.. 26.1639-1647.

Schindler. D. W. 1989. 'Biotic impoverishment at home and abroad'. BioScience, 39, 426.

Schindler. D. W. and Bayley. S. E. 1993. 'The biosphere as an increasing sink for atmospheric carbon: estimates from increased nitrogen deposition'. Global Biogeochem. Cycles, 7, 717-733.

Schindier. D. W.. Beaty. K. G.. Fee. E. J.. Cruikshank. D. R., DeBruyn, E. R., Findlay, D. L., Linsey, G. A., Shearer, J. A.. Stainton. M. P.. and Turner, M. A. 1990. 'Effects of climatic warming on lakes of the central boreal forest', Science, 250. 9677970.

Schlesinger, M. E. and Zhao. Z. 1989. Seasonal climatic changes induced by doubled $\mathbf{C O}_{2}$ as simulated by the OSU atmospheric GCM/Mixed-layer ocean model', J.Clim.. 2. 459-495.

Schwarz. H. E. and Dillard, L. A. 1990. 'Urban water', in Waggoner, P. E. (Ed.), Climate Change and U.S. Water Resources. Wiley, New York. pp. 341-366.

Shuter, B. J. and Post. J. R. 1990. Climate. population viability, and the zoogeography of temperate fishes', Trans. Am. Fish. SOC.. 119. $314-336$

Smith. D. S. 1990. 'The Adirondack Park in the 21st Century', Technical Reporı No. 20. Forest Resources of the Adirondacks.

Sorensen. J. A., Glass. G. E., Schmidt, K. W., Huber, J. K., and Rapp, G. R.. Jr. 1990. 'Airborne mercury deposition and watershed characteristics in relation to mercury concentrations in water sediments plankton and fish of eighty northern Minnesota lakes, USA'. Environ. Sci.Technol..24,1716-1727.

Spry, D. J. and Wiener, J. G. 1991. 'Metal bioavailability and toxicity to fish in low alkalinity lakes: a critical review', Environ. Pollut., 71. $243-304$.

Stemberger, R. S. and Lazorchak, J. M. 1994. 'Zooplankton assemblage responses to disturbance gradients', Con. J.Fish. Aquar. Sci., 51. 2435-2447.

Strayer, D. 1987. 'Ecology and zoogeography of the freshwater mollusks of the Hudson River basin', Malacol. Rev., 20. I-68.

Sweeney, B. W., Jackson. J. K., Newbold, J. D., and Funk, D. H. 1992. Climate change and the life histories and biogeography of aquatic insects in eastern North America', in Firth, P. and Fisher, S. G. (Eds), Global Climate Chonge ond Freshwater Ecosystems. Springer-Verlag. New York. pp. 143- 176.

Thornthwaite, C. W. and Mather. J. R. 1955. 'The water balance', Publ.Climatol., 8, 1-86.

Tiner, R .W. 1984. Wetlands of the United Stares: Current Status and RecentTrends. US Fish and Wildlife Service, National Wetlands Inventory, Washington, D.C. GPO.

US Congress. Office of Technology Assessment, 1993. 'Harmful non-indigenous species in the United States'. 0TA-F-565. US Govement Printing Office, Washington. D.C.

US DOA (Department of Agriculture), 1994. Summary Report, 1992 Norional Resources Inventory. U.S. Department of Agriculture, Soil Conservation Service, Washington, D.C.

US EPA (Environmental Protection Agency). 1994. 'National water quality inventory: 1992 report to Congress', EPA 841-R-94-001 US Environmental Protection Agency, Washington, D.C.

Vannote, R. L. and Sweeney, B. W. 1980. 'Geographic analysis of thermal equilibria', Am. Nut., 5, 667-695.

Verry, E. S. 1986. 'Forest harvesting and water: the lake states experience', Wat. Resour. Bull., 22, 1039-1047.

Ward. A. K.. Ward. G. M., Harlin, J. and Donahoe, R. 1990. 'Geological mediation of stream flow and sediment and solute loading to stream ecosystems due to climate change, in Firth, P. and Fisher, S. G. (Eds), Global Climate Change and Freshwater Ecosysiems. Springer-Verlag. New York. pp. 116-142.

Whitney, G. G. 1994. From Coastal Wilderness to Fruited Plain: A History of Environmental Change in Temperate North America, 1500 to rhe Present. Cambridge University Press, Cambridge. p. 451.

Wilkie. R. W. and Tager. J. 1991. Historical Atlas of Massachusetts. University of Massachusetts Press. Amherst. MA.

Wilson. C. A. and Mitchell, J. F. B. 1987. 'A doubled $\mathrm{CO}_{2}$ climate sensitivity experiment with a global climate model including a simple ocean', J. Geophys. Res., 91, 13315-13343.

Wofsy, S.. Goulden, M. L., Munger, J. W., Fan, S. M., Bakwin, P. S., Daube, B. C., Bassow, S. L. and Bazzaz. F. A. 1993. 'Net exchange of $\mathbf{C O}_{2}$ in a midlatitude forest', Science, 260, 1314-1317.

Yeardley, R. B. and Lazorchak. J. M. 1994. 'Results of the 1993 EMAP-Surface waters Northeast Lakes Pilot: fish tissue contaminants'. Abstract and poster, 1994. Annual Meeting, Society of Environmental Techology and Chemistry (SETAC). 